\title{
Turkey: Trade Policy Review
}

\author{
Sübidey Togan \\ Bilkent University, Ankara
}

\section{INTRODUCTION}

\begin{abstract}
$\mathfrak{T}$ HE Trade Policy Review: Turkey 2003, the third of its kind, provides a comprehensive survey of trade policy developments and practices in Turkey. This paper discusses besides the principal issues highlighted in the report, an issue that has largely been neglected in Trade Policy Reviews. It is the sustainability of current account. Section 2 describes the main developments in Turkey's trade regime and trade performance, and Section 3 examines the trade policy under the headings of measures affecting imports, exports and foreign direct investment. Section 4 is on liberalisation of services, and Section 5 on sustainability of current account. The final section offers conclusions.
\end{abstract}

\section{MAIN DEVELOPMENTS}

Until the early 1980s Turkey was a fairly closed economy. At that time - as part of more wide-ranging economic reforms - the trade policy of protection and import substitution was replaced by a much more open trade regime.

\section{a. Trade Agreements}

Turkey acceded to the GATT in 1951 under the Torquay Protocol, has participated in all subsequent rounds of multilateral trade negotiations, and became an original Member of the World Trade Organisation (WTO) on 26 March, 1995. It is according to its trade partners at least MFN treatment, and has preferential trade agreements with a number of countries. It has amended legislation in the areas of intellectual property, safeguards, anti-dumping and countervailing measures. Turkey has made extensive commitments under the General Agreement on Trade in Services (GATS). Turkey is not a signatory to the Plurilateral Agreements that resulted from the Uruguay Round; it is an observer to the Plurilateral Agreements on Government Procurement and Trade in Civil Aircraft. It is attaching great importance to the Doha Development Agenda. To date Turkey has been involved in several cases under the WTO dispute settlement mechanism. Seven 
consultations have been requested regarding Turkey's trade measures and Turkey has been the complainant in two cases.

Turkey applied for associate membership in the EU - then the EEC - as early as 1959. The application resulted in an Association Agreement in 1963, whereby Turkey and the EU would conditionally and gradually create a customs union by 1995 at the latest. The customs union was seen as a step towards full membership at an unspecified future date. The EU unilaterally granted Turkey preferential tariffs and financial assistance, but the process of staged, mutual reductions in tariffs and non-tariff barriers was delayed in the 1970s because of economic and political conditions in Turkey. Turkey applied for full membership in 1987. The response in 1990 was that accession negotiations could not be undertaken at the time, since the EU was engaged in major internal changes and as well as in the transition of Eastern Europe and the Soviet Union. However, the EU was prepared to extend economic relations without explicitly rejecting the possibility of full membership at a future date.

Turkey joined the European Customs Union (CU) starting 1 January, 1996. According to the Customs Union Decision (CUD) of 1995, all industrial goods, except products of the European Coal and Steel Community (ECSC), that comply with the European Community norms could circulate freely between Turkey and the EU as of 1 January, 1996. For ECSC products, Turkey signed a free trade agreement (FTA) with the EU in July 1996, and, as a result, ECSC products have received duty-free treatment between the parties since 1999.

The CUD required Turkey to implement the European Community's Common Customs Tariffs (CCT) on imports of industrial goods from third countries as of 1 January, 1996, to adopt by 2001 all of the preferential trade agreements the EU has concluded over time, and to implement on the commercial policy side measures similar to those of the European Community's commercial policy. Adhering to the stipulations of the CUD, Turkey maintained rates of protection above those specified in the CCT for certain 'sensitive' products until 2001. In order to adopt the EU's preferential trade agreements, Turkey signed FTAs with the European Free Trade Association countries, Israel, and the Central and Eastern European countries. FTAs are being discussed with the Mediterranean countries. In addition, Turkey has adopted the EC competition law, established the Competition Board, adopted the EC rules on protection of intellectual and industrial property rights, established a Patent Office, and started to harmonise technical legislation concerning industrial products and the establishment of sound conformity assessment and market surveillance structures internally.

On 10-11 December, 1999, the European Council meeting held in Helsinki produced a breakthrough in Turkey-EU relations. At Helsinki, Turkey was officially recognised as a candidate state for accession, on an equal footing with other candidate states. It now has a so-called Accession Partnership with the EU, which means that the EU is working together with Turkey to enable it to adopt the 
acquis communautaire, the legal framework of the EU. In contrast to other candidate countries, Turkey did not receive a timetable for accession. After the approval of the Accession Partnership by the Council and the adoption of the Framework Regulation on 26 February, 2001, the Turkish Government announced its own National Programme for the adoption of the acquis communautaire on 19 March, 2001. Progress towards accession continues along the path set by the National Programme.

In late 2004 another milestone was reached with the recommendation of the Commission of the European Communities that the European Council endorse the launching of formal accession negotiations and establish a timetable. The Copenhagen European Council in December 2002 concluded that:

if the European Council in December 2004, on the basis of a report and a recommendation from the Commission, decides that Turkey fulfils the Copenhagen political criteria, the European Union will open accession negotiations with Turkey without delay.

The December 2004 Council decided to start membership talks with Turkey on 3 October, 2005.

In addition to the Customs Union with the EU and the FTA with the EFTA, Turkey also participates in the Economic Cooperation Organisation (ECO) and the Black Sea Economic Cooperation (BSEC). The ECO is an intergovernmental regional organisation established in 1985 by Iran, Pakistan and Turkey for the purpose of sustainable socio-economic development of member states. In 1992, the Organisation was expanded to include Afghanistan, Azerbaijan, Kazakhstan, Kyrgyz Republic, Tajikistan, Turkmenistan and Uzbekistan. On 17 July, 2003, the ECO Trade Agreement (ECOTA) was signed between Afghanistan, Iran, Pakistan, Tajikistan and Turkey. The Agreement foresees the reduction of tariffs to a maximum of 15 per cent within a maximum period of eight years. ECOTA has binding provisions on state monopolies, state aid, protection of intellectual property rights, dumping and anti-dumping measures. On the other hand, the BSEC aims to improve and diversify economic and trade relations between its eleven members. The member countries are Albania, Armenia, Azerbaijan, Bulgaria, Georgia, Greece, Moldavia, Romania, the Russian Federation, Turkey and Ukraine. The BSEC Declaration was signed on 25 June, 1992, and on 7 February, 1997, a declaration of intent for the establishment of a BSEC free trade area was adopted. Recently, BSEC launched projects to eliminate non-tariff barriers on regional trade and to harmonise trade documents in the region.

\section{b. Investment Framework}

Foreign-owned firms had long been subject to special authorisations and sectoral limitations. In 2001 the Turkish government requested the Foreign Investment Advisory Service of the World Bank to conduct a study on the business 
environment affecting foreign direct investment (FDI) firms in Turkey. The study was conducted in cooperation with the Undersecretariat for the Treasury. According to Foreign Investment Advisory Service (2001a and 2001b) seven major problems impeded the operations of FDI enterprises up until the early 2000s: (i) political instability, (ii) government hassle, (iii) a weak judicial system, (iv) heavy taxation, (v) corruption, (vi) deficient infrastructure and (vii) competition from the informal economy. On the basis of this work, a new Law on FDI and important amendments in various laws (Commercial Law and in the laws concerning the Employment of Foreigners, the Registry of Title Deeds and Public Procurement) were adopted by the Parliament in 2003. The new legislation removed the screening and pre-approval procedures for FDI projects, re-designed the company registration process on an equal footing for domestic and foreign firms, facilitated the hiring of foreign employees, included FDI firms in the definition of 'domestic tenderer' in public procurement, and authorised foreign persons and companies to acquire real estate in Turkey. Thus the new law guarantees national treatment and investor rights. According to the law a company can be 100 per cent foreign owned in almost all sectors of the economy. Acquisitions of more than 30 hectares by foreigners are subject to permission from the Council of Ministers, and establishments in the financial, petroleum and mining sectors require special permission, according to appropriate laws.

\section{c. Trade Performance and Investment}

Basic data on Turkey's merchandise trade are shown in Tables 1 and 2. The tables reveal that in 2004 Turkish merchandise exports amounted to US\$63 billion and merchandise imports to $\$ 97.3$ billion. ${ }^{1}$ Exports to the EU15 made up 54.6 per cent of total exports, and imports from the EU made up 46.6 per cent of total imports.

Table 1 reveals that the three export commodities with the highest shares of total exports during 2003 were clothing, 21.1 per cent; textiles, 11.1 per cent; and automotive products, 10.4 per cent. The three import commodities with the highest shares of total imports were fuels, 16.7 per cent; other non-electrical machinery, 10.5 per cent; and automotive products, 9 per cent. Similarly, the three export commodities with the highest shares of exports to the EU were clothing, 30.2 per cent; automotive products, 13.4 per cent; and textiles, 10 per cent. The three commodities with the highest shares of imports from the EU were automotive products, 17.4 per cent; other non-electricial machinery, 15.5 per cent; and other semi-manufactures, 7.6 per cent.

During the period 1990-2003, Turkey's total exports grew at an annual rate of 9 per cent and total imports at the rate of 8.3 per cent. The export commodities

\footnotetext{
${ }^{1}$ All dollar amounts are US dollars unless otherwise indicated.
} 
TABLE 1

Exports and Imports, Turkey

\begin{tabular}{|c|c|c|c|c|c|c|c|c|}
\hline SITC & Commodity & $\begin{array}{l}\text { Total } \\
\text { Exports, } \\
2003 \\
\text { (US\$ } \\
\text { millions) }\end{array}$ & $\begin{array}{l}\text { Percentage } \\
\text { Distribution, } \\
\text { Total } \\
\text { Exports }\end{array}$ & $\begin{array}{l}\text { Annual } \\
\text { Growth Rate } \\
\text { of Exports, } \\
1990-2003 \\
\text { (Per cent) }\end{array}$ & $\begin{array}{l}\text { Exports } \\
\text { to the } \\
\text { EU } 2003 \\
\text { (US\$ } \\
\text { millions) }\end{array}$ & $\begin{array}{l}\text { Percentage } \\
\text { Distribution, } \\
\text { Exports } \\
\text { to EU }\end{array}$ & $\begin{array}{l}\text { Share of } \\
\text { Exports to } \\
\text { EU of } \\
\text { Sectoral } \\
\text { Exports }\end{array}$ & $\begin{array}{l}\text { Annual } \\
\text { Growth Rate } \\
\text { of Exports } \\
\text { to EU, } \\
\text { 1990-2003 } \\
\text { (Per cent) }\end{array}$ \\
\hline & Agricultural Products & & & & & & & \\
\hline $0+1+4+22$ & Food & 4,735 & 10.03 & 2.01 & 1,949 & 8.31 & 41.17 & 2.32 \\
\hline $2-22-27-28$ & $\begin{array}{l}\text { Agricultural raw materials } \\
\text { Mining Products }\end{array}$ & 522 & 1.11 & 2.56 & 220 & 0.94 & 42.24 & 0.41 \\
\hline $27+28$ & Ores and other minerals & 572 & 1.21 & 4.23 & 246 & 1.05 & 42.95 & 2.56 \\
\hline 3 & Fuels & 980 & 2.08 & 7.93 & 211 & 0.90 & 21.53 & -0.31 \\
\hline 68 & $\begin{array}{l}\text { Non-ferrous metals } \\
\text { Manufactures }\end{array}$ & 457 & 0.97 & 8.64 & 222 & 0.94 & 48.45 & 9.03 \\
\hline 67 & $\begin{array}{l}\text { Iron and steel } \\
\text { Chemicals }\end{array}$ & 3,342 & 7.08 & 5.12 & 939 & 4.00 & 28.09 & 16.52 \\
\hline 51 & Organic chemicals & 171 & 0.36 & 1.53 & 107 & 0.46 & 62.55 & 4.28 \\
\hline $57+58$ & Plastics & 545 & 1.15 & 9.20 & 112 & 0.48 & 20.50 & 5.40 \\
\hline 52 & Inorganic chemicals & 230 & 0.49 & 5.99 & 80 & 0.34 & 34.68 & 5.38 \\
\hline $53+55+56+59$ & Other chemicals & 726 & 1.54 & 10.19 & 65 & 0.28 & 8.97 & 4.00 \\
\hline $6-65-67-68$ & $\begin{array}{l}\text { Other semi-manufactures } \\
\text { Machinery and transport equipment }\end{array}$ & 4,143 & 8.77 & 12.52 & 1,645 & 7.01 & 39.70 & 12.21 \\
\hline $71-713$ & Power-generating machinery & 246 & 0.52 & 24.80 & 85 & 0.36 & 34.47 & 22.77 \\
\hline $72+73+74$ & Other non-electrical machinery & 1,566 & 3.32 & 18.16 & 537 & 2.29 & 34.29 & 17.73 \\
\hline $75+76+776$ & Office machines and tel. equipment & 1,978 & 4.19 & 17.99 & 1,569 & 6.68 & 79.30 & 17.27 \\
\hline $77-776-7783$ & Electrical machinery and apparatus & 2,076 & 4.40 & 16.83 & 999 & 4.26 & 48.14 & 14.64 \\
\hline $\begin{array}{l}78-785-786 \\
\quad+7132+7783\end{array}$ & Automotive products & 4,928 & 10.44 & 24.42 & 3,139 & 13.38 & 63.70 & 29.30 \\
\hline $\begin{aligned} 79 & +785+786+7131 \\
& +7133+7138+7139\end{aligned}$ & Other transport equipment & 1,542 & 3.27 & 20.70 & 853 & 3.63 & 55.31 & 23.07 \\
\hline 65 & Textiles & 5,262 & 11.14 & 10.14 & 2,340 & 9.97 & 44.48 & 7.50 \\
\hline 84 & Clothing & 9,962 & 21.10 & 7.21 & 7,079 & 30.17 & 71.07 & 5.94 \\
\hline $8-84-86-891$ & Other consumer goods & 2,675 & 5.67 & 16.37 & 954 & 4.06 & 35.66 & 12.44 \\
\hline $9+891$ & Other Products & 335 & 0.71 & 30.17 & 44 & 0.19 & 13.02 & 16.10 \\
\hline Total & & 47,253 & 100 & 9.01 & 25,899 & 100 & 54.81 & 8.56 \\
\hline
\end{tabular}


TABLE 1 Continued

\begin{tabular}{|c|c|c|c|c|c|c|c|c|}
\hline & & $\begin{array}{l}\text { Total } \\
\text { Imports, } \\
2003 \\
\text { (US\$ } \\
\text { millions) }\end{array}$ & $\begin{array}{l}\text { Percentage } \\
\text { Distribution, } \\
\text { Total } \\
\text { Imports }\end{array}$ & $\begin{array}{l}\text { Annual } \\
\text { Growth Rate } \\
\text { of Imports, } \\
\text { 1990-2003 } \\
\text { (Per cent) }\end{array}$ & $\begin{array}{l}\text { Imports } \\
\text { from } \\
\text { EU } 2003 \\
\text { (US\$ } \\
\text { millions) }\end{array}$ & $\begin{array}{l}\text { Percentage } \\
\text { Distribution, } \\
\text { Imports } \\
\text { from EU }\end{array}$ & $\begin{array}{l}\text { Share of } \\
\text { Imports } \\
\text { from } \\
\text { EU of } \\
\text { Sectoral } \\
\text { Imports }\end{array}$ & $\begin{array}{l}\text { Annual } \\
\text { Growth Rate } \\
\text { of Imports } \\
\text { from EU, } \\
1990-2003 \\
\text { (Per cent) }\end{array}$ \\
\hline \multicolumn{9}{|c|}{ Agricultural Products } \\
\hline $0+1+4+22$ & Food & 2,789 & 4.03 & 3.29 & 548 & 1.85 & 19.65 & 1.70 \\
\hline \multicolumn{9}{|c|}{$\begin{array}{l}\text { Agricultural raw materials } \\
\text { Mining Products }\end{array}$} \\
\hline $27+28$ & Ores and other minerals & 2,262 & 3.26 & 4.58 & 670 & 2.26 & 29.61 & -0.05 \\
\hline 3 & Fuels & 11,575 & 16.71 & 8.06 & 460 & 1.55 & 3.97 & 7.71 \\
\hline 68 & Manufactures & 1,411 & 2.04 & 9.55 & 308 & 1.04 & 21.80 & 4.23 \\
\hline \multicolumn{9}{|c|}{ Chemicals } \\
\hline 51 & Organic chemicals & 2,102 & 3.03 & 7.39 & 1,059 & 3.57 & 50.39 & 6.83 \\
\hline $57+58$ & Plastics & 2,837 & 4.09 & 12.80 & 1,645 & 5.54 & 58.00 & 11.57 \\
\hline 52 & Inorganic chemicals & 543 & 0.78 & 2.82 & 178 & 0.60 & 32.78 & 0.99 \\
\hline 54 & Pharmaceuticals & 2,302 & 3.32 & 17.09 & 1,546 & 5.21 & 67.14 & 17.05 \\
\hline $53+55+56+59$ & Other chemicals & 2,643 & 3.82 & 7.00 & 1,560 & 5.26 & 59.03 & 7.65 \\
\hline $6-65-67-68$ & Other semi-manufactures & 3,489 & 5.04 & 8.27 & 2,245 & 7.56 & 64.33 & 7.66 \\
\hline \multicolumn{9}{|c|}{ Machinery and transport equipment } \\
\hline $71-713$ & Power-generating machinery & 758 & 1.09 & 12.52 & 382 & 1.29 & 50.34 & 12.44 \\
\hline $72+73+74$ & Other non-electrical machinery & 7,250 & 10.46 & 5.21 & 4,607 & 15.52 & 63.54 & 4.18 \\
\hline $75+76+776$ & Office machines and tel. equipment & 4,166 & 6.01 & 10.95 & 1,618 & 5.45 & 38.83 & 12.15 \\
\hline $77-776-7783$ & Electrical machinery and apparatus & 2,065 & 2.98 & 6.82 & 1,175 & 3.96 & 56.93 & 5.75 \\
\hline $\begin{array}{l}78-785-786 \\
\quad+7132+7783\end{array}$ & Automotive products & 6,209 & 8.96 & 11.67 & 5,150 & 17.35 & 82.95 & 13.91 \\
\hline $\begin{array}{c}79+785+786+7131 \\
+7133+7138+7139\end{array}$ & Other transport equipment & 1,012 & 1.46 & 1.80 & 711 & 2.40 & 70.29 & 4.88 \\
\hline 65 & Textiles & 3,441 & 4.97 & 13.03 & 1,185 & 3.99 & 34.43 & 13.49 \\
\hline 84 & Clothing & 422 & 0.61 & 24.93 & 204 & 0.69 & 48.26 & 21.68 \\
\hline $8-84-86-891$ & Other consumer goods & 3,540 & 5.11 & 10.07 & 1,910 & 6.44 & 53.96 & 9.27 \\
\hline $9+891$ & Other Products & 2,714 & 3.92 & 27.10 & 391 & 1.32 & 14.42 & 18.75 \\
\hline Total & & 69,340 & 100 & 8.27 & 33,495 & 100 & 48.31 & 8.06 \\
\hline
\end{tabular}

Note: SITC $=$ Standard International Trade Classification. Source: Own calculations based on data provided by State Institute of Statistics. 
with the highest annual growth rates were other products, 30.2 per cent; powergenerating machinery, 24.8 per cent; and automotive products, 24.4 per cent. The import commodities with the highest growth rates were other products, 27.1 per cent; clothing, 24.9 per cent; and pharmaceuticals, 17.1 per cent. Similarly, the export commodities to the EU with the highest growth rates were automotive products, 29.3 per cent; other transport equipment, 23.1 per cent; and powergenerating machinery, 22.8 per cent. The imported commodities from the EU with the highest growth rates were clothing, 21.7 per cent; other products, 18.8 per cent; and pharmaceuticals, 17.1 per cent.

A look at the EU's share of total sectoral exports reveals that highest shares of exports to the EU are held by office machines and telecommunications equipment, 79.3 per cent; clothing, 71.1 per cent; and automotive products, 63.7 per cent. Among the sectors considered, other chemicals, other products, and plastics have the lowest shares. The three sectors with the highest EU shares of sectoral imports are automotive products, 83 per cent; other transport equipment, 70.3 per cent; and pharmaceuticals, 67.1 per cent. Among the sectors considered, fuels, other products, and food have the lowest EU shares of sectoral imports.

Table 2 shows the evolution of Turkish trade with the EU over the period 1990-2004. The data reveal that with the formation of the customs union the share of imports from the EU of total imports went up from 47.2 in 1995 to 53 per cent in 1996, but then began to decrease, reaching 46.6 per cent in 2004. Comparison of the growth rate of Turkish imports from the EU prior to formation of the customs union with that observed after formation of the customs union shows that the average growth rate of imports has even declined, from 9.1 per cent during 1990-95 to -1.76 per cent during 1996-2002, and then increased to 39.5 per cent during 2003-04. The effect of the customs union on exports seems to be of limited importance initially. Whereas the annual average growth rate of Turkish exports to the EU was 7.5 per cent prior to formation of the customs union, it increased to 7.2 per cent over the period 1996-2002, and then to 36.6 per cent during 2003-04. Similarly, the share of exports to the EU of total exports increased from 51.2 per cent in 1995 to 54 per cent in 1999, but thereafter the share declined to 51.5 per cent in 2002 , and then increased to 54.6 per cent in 2004. Finally, Table 2 reveals that Turkey has run a trade deficit with the EU during every year of the period 1996-2004 and that the deficit has been substantial by any standard. It reached $\$ 12.6$ billion in 1997 and $\$ 11$ billion in 2004 .

These findings reveal that the formation of the customs union between Turkey and the EU did not lead initially to substantial increases in trade with the EU. Substantial increases in trade with the EU were achieved only during the period 2002-03. The reasons vary. First, the formation of the customs union did not lead to substantial reductions in trade barriers on the EU side, because the EU had abolished the nominal tariff rates on imports of industrial goods from Turkey on 1 September, 1971, long before the formation of the customs union. But at 
TABLE 2

Trade with EU, 1990-2004

\begin{tabular}{|c|c|c|c|c|c|c|c|c|c|c|c|c|}
\hline & $\begin{array}{l}\text { Total } \\
\text { Imports } \\
\text { (US\$ } \\
\text { millions) }\end{array}$ & $\begin{array}{l}\text { Imports } \\
\text { from EU } \\
\text { (US\$ } \\
\text { millions) }\end{array}$ & $\begin{array}{l}\text { Growth } \\
\text { Rate } \\
\text { of Total } \\
\text { Imports } \\
\text { (Per cent) }\end{array}$ & $\begin{array}{l}\text { Growth } \\
\text { Rate } \\
\text { of Imports } \\
\text { from EU } \\
\text { (Per cent) }\end{array}$ & $\begin{array}{l}\text { Share of } \\
\text { Imports } \\
\text { from EU } \\
\text { of Total } \\
\text { Imports }\end{array}$ & $\begin{array}{l}\text { Total } \\
\text { Exports } \\
\text { (US\$ } \\
\text { millions) }\end{array}$ & $\begin{array}{l}\text { Exports } \\
\text { to EU } \\
\text { (US\$ } \\
\text { millions) }\end{array}$ & $\begin{array}{l}\text { Growth } \\
\text { Rate } \\
\text { of Total } \\
\text { Exports } \\
\text { (Per cent) }\end{array}$ & $\begin{array}{l}\text { Growth } \\
\text { Rate of } \\
\text { Exports } \\
\text { to EU } \\
\text { (Per cent) }\end{array}$ & $\begin{array}{l}\text { Share of } \\
\text { Exports } \\
\text { to EU } \\
\text { of Total } \\
\text { Exports }\end{array}$ & $\begin{array}{l}\text { Trade } \\
\text { Balance } \\
\text { with } \\
\text { EU (US\$ } \\
\text { millions) }\end{array}$ & $\begin{array}{l}\text { Real } \\
\text { Exchange } \\
\text { Rate }\end{array}$ \\
\hline 1990 & 22,302 & 9,898 & & & 44.38 & 12,959 & 7,177 & & & 55.38 & $-2,721$ & 99.67 \\
\hline 1991 & 21,047 & 9,987 & -5.63 & 0.90 & 47.45 & 13,594 & 7,348 & 4.90 & 2.38 & 54.05 & $-2,639$ & 96.66 \\
\hline 1992 & 22,870 & 10,656 & 8.66 & 6.70 & 46.59 & 14,719 & 7,937 & 8.28 & 8.02 & 53.92 & $-2,719$ & 100.94 \\
\hline 1993 & 29,429 & 13,875 & 28.68 & 30.21 & 47.15 & 15,348 & 7,599 & 4.27 & -4.26 & 49.51 & $-6,276$ & 91.59 \\
\hline 1994 & 23,270 & 10,915 & -20.93 & -21.33 & 46.91 & 18,105 & 8,635 & 17.96 & 13.63 & 47.69 & $-2,280$ & 124.35 \\
\hline 1995 & 35,708 & 16,861 & 53.45 & 54.48 & 47.22 & 21,636 & 11,078 & 19.50 & 28.29 & 51.20 & $-5,783$ & 116.72 \\
\hline 1996 & 43,627 & 23,138 & 22.18 & 37.23 & 53.04 & 23,224 & 11,549 & 7.34 & 4.25 & 49.73 & $-11,589$ & 116.67 \\
\hline 1997 & 48,559 & 24,870 & 11.30 & 7.49 & 51.22 & 26,261 & 12,248 & 13.08 & 6.05 & 46.64 & $-12,622$ & 110.32 \\
\hline 1998 & 45,921 & 24,075 & -5.43 & -3.20 & 52.43 & 26,974 & 13,498 & 2.72 & 10.21 & 50.04 & $-10,577$ & 100.42 \\
\hline 1999 & 40,687 & 21,417 & -11.40 & -11.04 & 52.64 & 26,589 & 14,349 & -1.43 & 6.30 & 53.97 & $-7,068$ & 94.30 \\
\hline 2000 & 54,509 & 26,610 & 33.97 & 24.25 & 48.82 & 27,775 & 14,510 & 4.46 & 1.12 & 52.24 & $-12,100$ & 85.17 \\
\hline 2001 & 41,399 & 18,280 & -24.05 & -31.30 & 44.16 & 31,334 & 16,118 & 12.81 & 11.08 & 51.44 & $-2,162$ & 106.33 \\
\hline 2002 & 51,554 & 23,321 & 24.53 & 27.57 & 45.24 & 36,059 & 18,459 & 15.08 & 14.52 & 51.19 & $-4,863$ & 96.11 \\
\hline 2003 & 69,340 & 33,495 & 34.50 & 43.62 & 48.31 & 47,253 & 25,899 & 31.04 & 40.31 & 54.81 & $-7,596$ & 88.23 \\
\hline 2004 & 97,341 & 45,373 & 40.38 & 35.46 & 46.61 & 63,017 & 34,399 & 33.36 & 32.82 & 54.59 & $-10,974$ & 83.93 \\
\hline \multicolumn{3}{|c|}{ Average 1990-95 } & 8.31 & 9.13 & 46.62 & & & 9.90 & 7.46 & 51.96 & & \\
\hline \multicolumn{3}{|c|}{ Average 1996-2002 } & 1.26 & -1.76 & 49.65 & & & 6.08 & 7.24 & 50.75 & & \\
\hline \multicolumn{3}{|c|}{ Average 2003-04 } & 37.44 & 39.54 & 47.46 & & & 32.20 & 36.56 & 54.70 & & \\
\hline
\end{tabular}

Source: State Planning Organisation (http://www.dpt.gov.tr); own calculations. 
that time certain exceptions were made. The European Community had retained the right to charge import duties on some oil products over a fixed quota and to implement a phased reduction of duties on imports of particular textile products. Moreover, the trade in products within the province of the ECSC have been protected by the Community through the application of non-tariff barriers and, in particular, anti-dumping measures. With the formation of the customs union, quotas applied by the EU were abolished, but the EU retained the right to impose anti-dumping duties.

Second, not until 2003 did Turkey incorporate into its internal legal order the European Community instruments related to removal of technical barriers to trade that would allow Turkish industrial products to enter into free circulation in the EU. Serious efforts to harmonise technical legislation concerning industrial products and the establishment of sound conformity assessment and market surveillance structures internally by Turkey were made only recently.

Third, during the 1990s economic crises began to affect Turkey with increasing frequency. Periods of economic expansion alternated with periods of equally rapid decline. Turkey faced a currency crisis in 1994 and 2001, and was hit by two severe earthquakes in 1999. GDP shrank considerably in 1994, 1999 and 2001. As a result of these developments, the country saw substantial decreases in import demand during 1994, 1999 and 2001.

Fourth, with the substantial reductions in trade barriers on the Turkish side during 1996, the increase in imports was inevitable, so long as it was not accompanied by a real devaluation of the Turkish lira. As Table 3 reveals, there was no change in the real exchange rate during 1996, and it then began to appreciate until the currency crisis of 2001. The real appreciation of the Turkish lira stimulated the import growth and hampered the growth of exports, leading to higher trade balance deficits. Also during the period 2001-04, the euro appreciated against the US dollar, leading to increases in the dollar value of EU exports, which was then reflected in the higher dollar trade values of Turkish imports from the EU and of exports to the EU.

Table 3 showing the FDI inflows over the period 1999-2003 reveals that the level of FDI inflow into Turkey is too low relative to FDI flows to developing countries with similar levels of GDP per capita. In particular, the FDI flows to Central and Eastern European countries are much larger than those to Turkey. The table indicates that manufacturing and services have attracted almost all FDI inflows into Turkey, and that the EU is the largest investor in Turkey.

\section{TRADE POLICY}

The main factors influencing the Turkish trading system are the WTO Agreements and Turkey's current and future trade relations with the EU. Over the last 
TABLE 3

Foreign Direct Investment in Turkey (US\$ million)

\begin{tabular}{lrrrrr}
\hline & 1999 & 2000 & 2001 & 2002 & 2003 \\
\hline Sectoral Breakdown & & & & & \\
$\quad$ Agriculture & 0 & 9 & 0 & 0 & 0 \\
Mining & 13 & 3 & 3 & 2 & 12 \\
Manufacturing & 353 & 932 & 846 & 78 & 338 \\
$\quad$ Services & 447 & 763 & 2,439 & 510 & 196 \\
Country Breakdown & & & & & \\
EU & 386 & 1,172 & 2,613 & 455 & 426 \\
Other OECD & 258 & 210 & 280 & 60 & 117 \\
Middle East & 155 & 184 & 0 & 5 & 0 \\
Others & 14 & 141 & 395 & 70 & 3 \\
Total FDI & 813 & 1,707 & 3,288 & 590 & 546 \\
Share of FDI in GNP (Per cent) & 0.44 & 0.85 & 2.28 & 0.32 & 0.22 \\
\hline
\end{tabular}

Source: Central Bank of Turkey.

decade Turkey has continued to progressively align its trade regime on that of the EU, and domestic legislation in Turkey has been amended to reflect both its EU and WTO commitments.

\section{a. Measures Affecting Imports}

Prior to the successful conclusion of the Uruguay Round, most favoured nation (MFN) tariffs in many sectors were not legally bound, and as such they could potentially be raised. This created a lack of security in market access, and produced detrimental trade effects. A major goal of the Uruguay Round of Multilateral Trade Negotiations was to increase the proportion of bound industrial tariffs, thus providing added protection to trade liberalisation commitments. As a result of the Uruguay Round negotiations, 46.3 per cent of tariff lines in Turkey are now bound (all tariff lines for agricultural products and some 36 per cent of the lines for non-agricultural products). In 2005 final bindings will range from zero to 225 per cent on agricultural products, and from zero to 102 per cent on non-agricultural goods. The simple average bound tariff rate is set to decline to 33.9 per cent in 2005 .

On the other hand the applied tariff schedules of Turkey are rather complex, consisting of a large number of lists comprising about 19,400 tariff lines classified at the HS 12-digit level for different country groups and countries. ${ }^{2}$ List I displays customs duties applied to imports of agricultural products, excluding fish and fishery products. List II shows customs duties to be applied to imports

\footnotetext{
${ }^{2}$ HS stands for the Harmonised Commodity Description and Coding System.
} 
of industrial products and products covered by the ECSC. Lists III and IV lay down customs duties applied to imports of processed agricultural products. List V displays reduced customs duties applied to imports of certain products used as raw materials in fertiliser, chemical, plastics, textile and electrical machinery industry. Turkey's tariff comprises ad valorem (98.5 per cent of tariff lines) and non-ad valorem rates consisting of specific, mixed, compound and formula duties. Specific taxes (Mass Housing Fund levy) are applied on the imports of 550 fish and fishery products specified in List IV. The mixed, compound and formula duties apply mainly on processed agricultural commodities. Here we note that in line with the CUD, processed agricultural products imported into Turkey from the EU are subject to customs duties comprising an industrial and agricultural component. While all industrial components enjoy duty-free treatment, few agricultural components are subject to preferential treatment. MFN customs duties still apply to most agricultural components, where these components are calculated by multiplying the quantity of primary agriculture product used in processing, according to an agreed set of ratios, by the specific rate charge.

Table 4 shows the nominal protection rates (NPR) prevailing in 2004, where all non-ad valorem tariffs have been converted to ad valorem equivalents. In the table average tariffs for three groups of countries are listed. These are the EU, GSP countries, and countries for which the MFN tariffs apply. In addition the Turkish tariff schedule lists the tariff rates for countries Turkey has free trade agreements with such as EFTA countries, Israel, Romania, Macedonia and Bosnia \& Herzegovina, also the GSP tariffs for the least developed countries. ${ }^{3}$ But the tariff rates for these countries are not shown in the table. In the table the average NPRs are shown for 21 aggregated HS commodity sections such as animal products, chemical products, textiles and vehicles.

The table reveals that in trade with the EU the simple average NPR is 8.21 per cent and weighted average NPR 1.25 per cent. Here weighted averages have been calculated by weighting the nominal tariffs on the commodities by their shares in total imports. The simple average tariff rate on imports from the GSP countries is 10.47 per cent and the weighted NPR 2.62 per cent. Finally, the simple average MFN tariff is 11.97 per cent and the weighted average NPR 4.11 per cent.

In trade with the EU 17 out of a total of 21 sectors have zero NPRs. Concentrating in the following on weighted average NPRs we note that the highest tariff rate (49.98 per cent) applies in the case of 'live animals and animal products'. The NPR on 'vegetable products' is 38.78 and on 'edible oils' 23.26. On the other hand in the case of trade with GSP countries and with countries for which the MFN tariffs apply the NPRs on 'live animals and animal products', 'vegetable

\footnotetext{
${ }^{3}$ The list of GSP countries and the list of least developed countries are specified in Annex Table 3 to the import regime (see www.igeme.gov.tr).
} 
TABLE 4

Nominal Protection Rates, 2004

(Per cent)

\begin{tabular}{|c|c|c|c|c|c|c|c|c|c|}
\hline$H S$ & Commodity & $\begin{array}{l}\text { Number } \\
\text { of Tariff } \\
\text { Lines }\end{array}$ & $\begin{array}{l}\text { Per Cent } \\
\text { of Total } \\
2003 \\
\text { Imports }\end{array}$ & $\begin{array}{l}\text { Applied } \\
\text { Mean } \\
\text { Tariffs } \\
\text { (Simple) } \\
\text { EU }\end{array}$ & $\begin{array}{l}\text { Applied } \\
\text { Mean } \\
\text { Tariffs } \\
\text { (Weighted) } \\
\text { EU }\end{array}$ & $\begin{array}{l}\text { Applied } \\
\text { Mean } \\
\text { Tariffs } \\
\text { (Simple) } \\
\text { GSP }\end{array}$ & $\begin{array}{l}\text { Applied } \\
\text { Mean } \\
\text { Tariffs } \\
\text { (Weighted) } \\
\text { GSP }\end{array}$ & $\begin{array}{l}\text { Mean } \\
\text { MFN } \\
\text { Tariffs } \\
\text { (Simple) } \\
\text { Others }\end{array}$ & $\begin{array}{l}\text { Mean } \\
\text { MFN } \\
\text { Tariffs } \\
\text { (Weighted) } \\
\text { Others }\end{array}$ \\
\hline $01-05$ & Live Animals; Animal Products & 1,116 & 0.21 & 70.41 & 49.98 & 74.06 & 52.18 & 74.07 & 52.18 \\
\hline $06-14$ & Vegetable Products & 868 & 2.23 & 28.03 & 38.78 & 28.27 & 38.89 & 28.30 & 38.89 \\
\hline 15 & Edible Oils & 243 & 0.51 & 19.10 & 23.26 & 19.45 & 23.30 & 19.58 & 23.34 \\
\hline $16-24$ & Prepared Foodstuffs, Beverages and Tobacco & 1,272 & 1.47 & 0.00 & 0.00 & 0.00 & 0.00 & 0.00 & 0.00 \\
\hline $25-27$ & Mineral Products & 457 & 14.48 & 0.00 & 0.00 & 0.08 & 0.02 & 0.62 & 0.42 \\
\hline $28-38$ & Chemical Products & 3,156 & 12.20 & 0.07 & 0.02 & 0.53 & 0.60 & 2.98 & 2.17 \\
\hline $39-40$ & Plastics and Rubber & 566 & 6.16 & 0.00 & 0.00 & 0.27 & 0.84 & 3.10 & 3.22 \\
\hline $41-43$ & Leather and Travel Goods & 294 & 1.33 & 0.00 & 0.00 & 0.45 & 0.37 & 2.20 & 1.81 \\
\hline $44-46$ & Wood Products & 329 & 0.57 & 0.00 & 0.00 & 0.58 & 1.50 & 1.98 & 3.10 \\
\hline $47-49$ & Cellulose Products, Paper and Paper Products & 444 & 1.79 & 0.00 & 0.00 & 0.00 & 0.00 & 0.00 & 0.00 \\
\hline $50-63$ & Textile and Textile Articles & 3,534 & 8.09 & 0.00 & 0.00 & 6.30 & 4.18 & 7.89 & 5.26 \\
\hline $64-67$ & Footwear and Miscellaneous Manufactures & 206 & 0.35 & 0.00 & 0.00 & 3.76 & 6.29 & 7.41 & 10.40 \\
\hline $68-70$ & Articles of Stone, Ceramics, Glass and Glass Products & 458 & 0.75 & 0.00 & 0.00 & 0.91 & 1.17 & 3.08 & 3.28 \\
\hline 71 & Precious and Semi-precious Articles & 104 & 4.49 & 0.00 & 0.00 & 0.00 & 0.00 & 0.98 & 0.11 \\
\hline $72-83$ & Base Metals and Articles of Base Metal & 1,892 & 7.31 & 0.00 & 0.00 & 2.63 & 3.95 & 3.82 & 4.86 \\
\hline $84-85$ & Machinery & 2,744 & 25.17 & 0.00 & 0.00 & 0.19 & 0.48 & 1.84 & 2.21 \\
\hline $86-89$ & Transport Equipment & 528 & 9.42 & 0.00 & 0.00 & 1.80 & 3.74 & 4.39 & 7.76 \\
\hline $90-92$ & Precision & 746 & 2.38 & 0.00 & 0.00 & 0.09 & 0.10 & 1.74 & 1.29 \\
\hline 93 & Arms and Ammunitions & 34 & 0.16 & 0.00 & 0.00 & 2.32 & 1.32 & 2.32 & 1.32 \\
\hline $94-96$ & Miscellaneous Manufactured Articles & 397 & 0.93 & 0.00 & 0.00 & 0.08 & 0.13 & 2.41 & 3.06 \\
\hline \multirow[t]{2}{*}{97} & Art and Antiques & 13 & 0.01 & 0.00 & 0.00 & 0.00 & 0.00 & 0.00 & 0.00 \\
\hline & Total & 19,401 & 100 & 8.21 & 1.25 & 10.47 & 2.61 & 11.97 & 4.11 \\
\hline
\end{tabular}

Source: Own calculations. 
products' and 'edible oils' are not much different from the tariff rates applied on imports from the EU. The figures show that the agricultural sector is heavily protected in Turkey. In trade with the GSP countries the most protected nonagricultural three sectors are 'footwear' (6.29 per cent), 'textiles' (4.18 per cent) and 'base metals' (3.95 per cent). In the case of trade with MFN countries the most protected non-agricultural three commodities are 'footwear' (10.4 per cent), 'transport equipment' (7.76 per cent) and 'textiles' (5.26 per cent).

Table 5 shows the nominal protection rates for the agricultural commodities in more detail. The table reveals that in trade with the EU the simple average NPR is 42.5 per cent and weighted average NPR 19.8 per cent. The simple average tariff rate on imports from the GSP countries is 45.6 per cent and the weighted NPR 21.2 per cent. Finally, the simple average MFN tariff is 45.8 per cent and the weighted average NPR 21.4 per cent.

Concentrating on the case of agricultural commodities we note that in the case of trade with the EU the highest weighted average NPR (120.43 per cent) applies in the case of 'meat and edible offal'. The NPR on 'milk and dairy products' is 96.91 per cent and on 'edible fruits and citrus fruits' 90.24 per cent. On the other hand in the case of trade with GSP countries and countries for which the MFN tariffs apply the highest weighted average NPRs are imposed on 'meat and edible offal', 'milk and dairy products' and 'sugar and sweets'. These tariff rates are not much different from the tariff rates applied on imports from the EU. On the other hand the lowest tariff rates apply in the cases of 'vegetable plaiting materials', 'hides and skin', 'wool and animal hair' and 'cotton'.

Tariff preferences on agricultural products granted under Turkey's trade agreements, are subject to tariff quotas. The tariff quotas applied in trade with the EU cover 34 items at the HS six-digit level including live bovine animals and their meat, butter, cheese and flower bulbs.

Regarding duty and tax concessions on imports we note that these concessions in Turkey are granted through two main programmes: the General Investment Encouragement Programme and Aids Granted to Small and Medium-sized Enterprise Investments. Under both programmes feasible investment projects that are found to be eligible by the Undersecretariat of the Treasury can benefit from customs duty exemptions on all machinery and equipment to be used in the physical plant. In addition under the inward processing (IP) regime Turkish manufacturers/exporters can import materials free of duties. Goods imported under the IP scheme are intended for re-export from customs territory of Turkey in the form of compensating products. The system works through suspension of duties and VAT until exports are produced, or re-imbursement based on a drawback method. Under the drawback system, import duties and VAT have to be paid when the goods enter for free circulation into Turkey.

The above considerations reveal that Turkish NPRs are, except for agricultural commodities, rather very low. Hence one could state that tariffs for Turkey are 
TABLE 5

Protection in Agriculture, 2004

\begin{tabular}{|c|c|c|c|c|c|c|c|c|c|c|}
\hline & $\begin{array}{l}\text { HS } \\
\text { Code }\end{array}$ & Description & $\begin{array}{l}\text { Number } \\
\text { of Tariff } \\
\text { Lines }\end{array}$ & $\begin{array}{l}2003 \\
\text { Imports } \\
\text { (\$ million) }\end{array}$ & $\begin{array}{l}\text { Applied } \\
\text { Mean } \\
\text { Tariffs } \\
\text { (Simple) } \\
\text { EU } \\
\text { (Per cent) }\end{array}$ & $\begin{array}{l}\text { Applied } \\
\text { Mean } \\
\text { Tariffs } \\
\text { (Weighted) } \\
\text { EU } \\
\text { (Per cent) }\end{array}$ & $\begin{array}{l}\text { Applied } \\
\text { Mean } \\
\text { Tariffs } \\
\text { (Simple) } \\
\text { GSP } \\
\text { (Per cent) }\end{array}$ & $\begin{array}{l}\text { Applied } \\
\text { Mean } \\
\text { Tariffs } \\
\text { (Weighted) } \\
\text { GSP } \\
\text { (Per cent) }\end{array}$ & $\begin{array}{l}\text { MFN } \\
\text { Tariffs } \\
\text { (Simple) } \\
\text { Third } \\
\text { Countries } \\
\text { (Per cent) }\end{array}$ & $\begin{array}{l}\text { MFN } \\
\text { Tariffs } \\
\text { (Weighted) } \\
\text { Third } \\
\text { Countries } \\
\text { (Per cent) }\end{array}$ \\
\hline \multirow[t]{6}{*}{ I. } & \multicolumn{10}{|c|}{ Live animals and animal products } \\
\hline & 1 & Live animals & 120 & 11.85 & 54.16 & 2.19 & 54.16 & 2.19 & 54.16 & 2.19 \\
\hline & 2 & Meat and edible offal & 241 & 0.18 & 137.89 & 120.43 & 137.96 & 120.43 & 137.96 & 120.43 \\
\hline & 3 & Fish and sea products & 479 & 32.41 & 36.15 & 34.16 & 46.07 & 42.39 & 46.07 & 42.39 \\
\hline & 4 & Milk and dairy products; eggs; honey & 229 & 52.34 & 93.30 & 96.91 & 90.26 & 97.28 & 90.26 & 97.28 \\
\hline & 5 & Other animal products & 47 & 33.06 & 3.49 & 7.91 & 3.56 & 7.91 & 3.70 & 7.91 \\
\hline \multirow[t]{10}{*}{ II. } & \multicolumn{10}{|c|}{ Vegetable products } \\
\hline & 6 & Plants and floriculture products & 52 & 15.70 & 18.76 & 5.30 & 19.22 & 6.41 & 19.22 & 6.41 \\
\hline & 7 & Vegetable, plants, roots and tubers & 168 & 27.57 & 20.52 & 18.63 & 20.58 & 18.74 & 20.58 & 18.74 \\
\hline & 8 & Edible fruits; citrus fruits & 202 & 80.34 & 42.49 & 90.24 & 42.49 & 90.24 & 42.49 & 90.24 \\
\hline & 9 & Coffee, tea, spices & 54 & 24.41 & 38.37 & 39.10 & 38.63 & 40.20 & 38.63 & 40.20 \\
\hline & 10 & Cereals & 64 & 696.67 & 36.25 & 56.41 & 36.28 & 56.41 & 36.28 & 56.41 \\
\hline & 11 & Products of the milling industry & 120 & 10.16 & 39.84 & 23.43 & 40.06 & 24.77 & 40.06 & 24.77 \\
\hline & 12 & Oilseeds, various seeds/fruits; industrial plants & 134 & 477.74 & 15.74 & 10.28 & 16.49 & 10.48 & 16.49 & 10.48 \\
\hline & 13 & Vegetable lacquers, resins, balsams & 47 & 38.07 & 0.85 & 0.69 & 1.58 & 0.90 & 2.11 & 0.98 \\
\hline & 14 & Vegetable plaiting materials & 27 & 3.36 & 0.00 & 0.00 & 0.00 & 0.00 & 0.00 & 0.00 \\
\hline \multirow[t]{2}{*}{ III. } & \multicolumn{10}{|c|}{ Animal or vegetable oils and fats } \\
\hline & 15 & Animal or vegetable oils and fats & 243 & 313.92 & 19.10 & 23.26 & 19.45 & 23.30 & 19.58 & 23.34 \\
\hline
\end{tabular}




\begin{tabular}{|c|c|c|c|c|c|c|c|c|c|c|}
\hline \multirow[t]{10}{*}{ IV. } & \multicolumn{10}{|c|}{ Foodstuffs, beverages, tobacco } \\
\hline & 16 & Products made from meat, fish, crustacea & 146 & 0.80 & 95.63 & 60.40 & 101.11 & 75.43 & 101.11 & 75.43 \\
\hline & 17 & Sugar and sweets & 68 & 34.10 & 72.47 & 89.67 & 84.07 & 92.77 & 84.19 & 92.78 \\
\hline & 18 & Cocoa and cocoa products & 29 & 198.90 & 11.64 & 2.09 & 29.76 & 5.63 & 30.48 & 6.28 \\
\hline & 19 & Cereal products, wheat floor, pastries & 88 & 51.78 & 6.97 & 10.45 & 23.38 & 31.06 & 23.52 & 31.06 \\
\hline & 20 & Foods made of vegetable, fruits and other plants & 381 & 15.37 & 54.44 & 51.28 & 55.02 & 53.37 & 55.06 & 53.44 \\
\hline & 21 & Various foods & 71 & 157.19 & 5.54 & 2.41 & 13.51 & 15.72 & 15.77 & 18.08 \\
\hline & 22 & Alcoholic and non-alcoholic beverages & 201 & 15.76 & 25.99 & 1.49 & 38.77 & 6.22 & 39.63 & 8.42 \\
\hline & 23 & Residues of food industry; fodders & 84 & 199.85 & 7.05 & 1.26 & 7.52 & 2.55 & 7.52 & 2.55 \\
\hline & 24 & Processed tobacco and substitutes & 204 & 234.88 & 23.28 & 18.83 & 25.75 & 21.69 & 26.88 & 22.93 \\
\hline V. & \multicolumn{10}{|c|}{ Hides, wool and cotton } \\
\hline & \multirow{3}{*}{\multicolumn{2}{|c|}{$\begin{array}{l}\text { 4101-4103 Hides and skin } \\
5101-5103 \text { Wool and animal hair } \\
5201-5203 \text { Cotton }\end{array}$}} & 95 & 440.48 & 0.00 & 0.00 & 0.00 & 0.00 & 0.00 & 0.00 \\
\hline & & & 119 & 49.70 & 0.00 & 0.00 & 0.00 & 0.00 & 0.00 & 0.00 \\
\hline & & & 33 & 674.84 & 0.00 & 0.00 & 0.00 & 0.00 & 0.00 & 0.00 \\
\hline \multicolumn{3}{|l|}{ Total } & 3,746 & $3,891.41$ & 42.47 & 19.79 & 45.63 & 21.20 & 45.81 & 21.41 \\
\hline
\end{tabular}

Source: Own calculations. 
largely a non-issue in the non-agricultural sector. We therefore turn now to consideration of non-tariff barriers (NTBs).

In Turkey import prohibition applies for 11 broad product categories such as narcotics, arms and ammunitions, and ozone-depleting substances for reasons such as environment, public security, health and public morals. Imports of 13 broad product categories such as electricity, natural gas, radioactivity-related items, explosives, telecommunications-related items and some machinery are subject to licensing. Importers of these items must obtain permission from the relevant authorities. In addition to security, safety and environmental reasons, the restrictions are intended to protect consumers, e.g. for assuring the suitability of imported vehicles for highways. In addition, Turkey has been applying import quotas on certain textile and clothing products since 1 January, 1996, as a requirement for harmonising its import policy with that of the EU.

Regarding contingent protectionism Turkey has reported initiation of 46 antidumping investigations, and imposition of 33 anti-dumping measures during the period 1995-2002. As of the end of 2004 Turkey had 34 definitive anti-dumping duties in force. Most of the anti-dumping investigations were against China, the EU, Korea, Thailand and Chinese Taipei, and measures have affected mostly textiles and clothing, base metal products, plastics and rubber articles, and manufacturers such as light lighters and pencils. On the other hand Turkey has so far not taken any countervailing measures, and safeguard actions under GATT Article XIX.

Regarding technical barriers to trade (product standards) we note that there is a challenge for both Turkish firms and government policy. In the case of the latter, there are a large number of norms to apply. According to Annex II of the Decision 2/97 of the 1997 Turkey-EU Association Council, Turkey was supposed to incorporate into its internal legal order 324 instruments that correspond to various EEC or EC regulations and directives. Currently, Turkey has incorporated into its legal order only 203 of these 324 instruments. In the meantime, the number of instruments that Turkey has to incorporate into its legal order has increased to 560, and Turkey has incorporated 276 of them. Thus progress has been rather slow.

Turkey also must establish the so-called quality infrastructure, a generic term encompassing the operators and operation of standardisation, testing, certification, inspection, accreditation and metrology (industrial, scientific and legal). In the EU, national quality infrastructures that function according to the same principles and obey the same rules are a critical element of the free circulation of goods in the Single Market. Turkey, as a member of a customs union with the EU and as a candidate country, has to align its national quality infrastructure to the European one. Products manufactured in a future EU member state must satisfy to the same requirements prevailing in the $\mathrm{EU}$, and conformity to these requirements must be demonstrated in the same 'harmonised' way and according to the same principles. 
Recently, Turkey has taken major steps to align with the acquis. Law 4703 on the Preparation and Implementation of Technical Legislation on Products, which entered into force in January 2002, has been supplemented by secondary legislation. This framework law provides the legal basis for harmonisation with the EC legislation. It defines the principles for product safety and for implementation of the old and new approach directives, including the conditions for placing products on the market; the obligations of the producers and distributors, conformity assessment bodies and notified bodies; market surveillance and inspection; withdrawal of products from the market; and notification procedures. ${ }^{4}$ The legislation on market surveillance, use and affixing of the CE conformity mark, working principles and procedures for the conformity assessment bodies and notified bodies, and notification procedures between Turkey and the EU for technical regulations and standards which apply to non-harmonised regulated areas entered into force during 2002. ${ }^{5}$ Furthermore, Turkey has adopted all of the 23 new approach directives that require affixing the $\mathrm{CE}$ conformity marking, and 18 of the directives entered into force up to the present time. They cover commodities and product groups such as low-voltage equipment, toys, simple pressure vessels, construction products, electromagnetic compatibility, gas appliances, personal protective equipment, machinery, medical devices, non-automatic weighing instruments, telecommunications terminal equipment, hot-water boilers, civil explosives, lifts and recreational crafts.

Overall, then, Turkey has advanced the harmonisation of its technical legislation both on a sectoral (vertical) basis and at a horizontal level. It is in the process of establishing the necessary structures on conformity assessment and market surveillance. By now Turkey has the legal basis on which accreditation could be based. In order to assign the notified bodies that would deal with the certification of products, the ministries have established the criteria for the selection of such bodies for the products covered by certain new approach directives. Although in Europe, as in Turkey, accreditation is not mandatory to be appointed as a notified

\footnotetext{
${ }^{4}$ Law 4703 is based on Council Directive 92/59/EEC on general product safety, Council Regulation $85 / \mathrm{C} 136 / 01$ on the new approach to technical harmonisation and standards, and the Council resolution of December 1989 on the global approach to conformity assessment.

${ }^{5}$ The legislation on market surveillance was prepared using Council Directive 92/59/EEC on general products safety, the Council resolution of December 1989 on the global approach to conformity assessment, Council Directive 88/378/EEC on the approximation of the laws of the member states on the safety of toys, and on European Commission (2000). The legislation on working principles and procedures for the conformity assessment bodies and notified bodies was prepared using the material in chapter 6 of European Commission (2000). The legislation on the use and affixing of the CE conformity mark is based on Council Decision 93/465/EEC on the modules for the various phases of the conformity assessment procedures and the rules for affixing and use of the CE conformity marking. Finally, the legislation on notification procedures between Turkey and the EU for technical legislation and standards is based on Council Directive 98/34/EC laying down a procedure for the provision of information in the field of technical standards and regulations and the relevant section of Decision 2/97 of the EC-Turkey Association Council.
} 
body, since the Turkish Ministries did not feel adequately prepared to select notified bodies, they made accreditation one of the criteria for their selection by signing protocols with the Turkish National Accreditation Body, TURKAK. ${ }^{6}$ However, the fact that TURKAK has been a member of the European Accreditation Agency since 2003 and yet has not signed any multilateral agreement with the European partners makes its accreditation non-functional. Thus, even though TURKAK has given accreditation to potential notified bodies, this accreditation is meaningless in the eyes of national accreditation bodies of the EU.

Because of this the market is also reluctant to use TURKAK, because TURKAK accreditation is not accepted within the EU. This situation presents Turkish conformity assessment bodies with a disadvantage. The relatively large Turkish firms wishing to obtain CE marking for products exported to the EU market usually contact local subsidiaries of European notified bodies that use their European laboratories for testing. But for other Turkish companies this process seems to be expensive and slow. The small and medium-sized enterprises (SMEs) that export products find it particularly difficult to pay the high costs. In Turkey, marking and certification parallel to the EU system are implemented only in the automotive sector.

Other than for the automotive sector, as of 2005 Turkey is suffering from a lack of certification bodies. To make its conformity assessment compatible with that in the EU, Turkey has opened up the certification, testing and calibration market to other Turkish actors. However, Turkish firms are reluctant to enter the market for conformity assessment bodies as long as uncertainties prevail regarding the acceptance of notified bodies by the European Commission. Some of the Turkish firms in cooperation with the notified bodies in the EU have entered the Turkish market. Over time competition will ensure lower costs for conformity assessment. The expense, time and unpredictability incurred in obtaining approvals can then be reduced by having products evaluated in Turkey once the Turkish notified bodies are accepted by the European Commission and joint ventures with notified bodies in the EU increase. These savings can be particularly important where rejection of products in the EU can create delays and necessitate additional shipping or other costs.

Although, in principle, standards are voluntary in Turkey, in the absence of a proper market surveillance system the technical ministries and the Undersecretariat of Foreign Trade have turned the standardisation regime and licensing before production into a mandatory regime in order to protect the market and the consumers. This pre-market control system gives the Turkish Standards Institute (TSE) a great deal of power. It is emphasised that the TSE has misused its power

${ }^{6}$ Under a law published on 27 October, 1999, TURKAK is the national accreditation body in all fields. But the regulations that gave the Turkish Standards Institute (TSE) and Turkish Scientific and Research Council (TUBITAK) the power to accredit are still in force. 
in several cases of imports and has created technical barriers to trade. The TSE asked for the technical files of the imported products when they entered the Turkish market, and the processing of the files took an unusually long time. There are also cases in which products bearing the CE marking were asked for further inspection. Yet the Turkish internal market is regulated largely through mandatory standards and marking issued by the TSE. Since 2004 products covered by directives on toy safety, medical devices, active implantable medical devices, low-voltage electrical equipment, electromagnetic compatibility and machinery are not subject to mandatory controls when imported and used in the internal market. But products covered by the remaining 12 new approach directives are subject to mandatory controls.

In Turkey, 500 standards are mandatory for the domestic market as well as for imports. For all of these the TSE occupies a monopoly position, and for 500 of them TSE certification is mandatory. For these mandatory standards, manufacturers mostly need first a TSE certificate and then a Ministry of Industry and Trade licence to put the products on the market.

As argued by numerous studies of the impacts of a customs union, abolition of such real trade costs are likely to generate significant gains for Turkey. Full implementation of the EU acquis on technical barriers to trade, with the accompanying institutional strengthening will constitute the major change over the status quo in terms of non-agricultural merchandise trade with the EU.

\section{b. Measures Affecting Exports}

In Turkey the exportation of certain commodities is subject to registration, and the exportation of some other commodities is prohibited for various reasons including environment, health or religious reasons. All other commodities can be exported freely. Exporters are required to register with the Exporters Association and their local Chamber of Commerce. A fee of 0.05 per cent of the f.o.b. value of exports is charged as a service commission. According to the regulations of the export regime, export prohibitions have been imposed on commodities such as game and wild animals, flower bulbs, ozone-depleting substances, wood and wood charcoal, antiques and archaeological works, and grapevine, fig, hazelnut, pistachio and olive plants. Although Turkey does in general not apply export quotas, Turkish exporters of certain textiles and clothing products are faced with quotas on the US and Canadian markets. Turkey does not auction its quotas. Quotas have been allocated mainly on the basis of past performance.

Regarding export incentives we note that as a result of the customs union between the EU and Turkey as well as Turkey's commitments vis-à-vis the WTO, Turkey has progressively revamped the incentives provided to exporters. Changes include the abolition of most direct export subsidies, streamlining its duty concessions programmes, elimination of corporate tax exemption, and the 
introduction of new export credit, guarantee and insurance programmes. Currently the following export subsidies are provided:

Cash subsidies are extended to a number of agricultural products and processed agricultural goods including cut flowers, frozen vegetables, frozen fruit and olive oil. Table 6 shows the subsidies extended to these commodities. From the table it follows that subsidies are quite substantial for various commodities, but that the applied subsidy rates cannot exceed specified maximum rates. These rates are set between 10 and 20 per cent of the value of exports, and between 27 and 100 per cent of the quantities exported. The commodities under subsidy cover 25.41 per cent of total agricultural exports.

Under duty concessions we note that under the General Investment Encouragement Programme and Aids Granted to Small and Medium-sized Enterprises Investments exporter/producers' feasible investment projects, that are found to be eligible by the Undersecretariat of the Treasury, can benefit from customs duty exemptions on all machinery and equipment to be used in the physical plant. Furthermore, exporters are exempt from a number of duties such as the stamp tax, and exporters can import duty free under the inward-processing regime scheme.

Preferential export credits are extended by the Turk Eximbank, which operates a large number of export credit, guarantee and insurance schemes. It supports exporters, export-oriented manufacturers and overseas investors with short-, medium- and long-term cash and non-cash credit programmes. Moreover, export receivables are discounted in order to promote sales on deferred payment conditions and to increase export trade volumes. During 2002 Turk Eximbank provided support to 14 per cent of Turkey's total exports. Turk Eximbank also offers a variety of insurance policies for Turkish exporters, investors and overseas contractors against commercial and political risks.

In addition to the above subsidies $R \& D$ projects that aim to increase the productivity in export industries can be subsidised up to 50 per cent of the cost of the project. Furthermore, projects related to technical barriers can be subsidised up to 50 per cent of the cost of the project, and subsidies are provided to export promotion activities of firms directed to the participation in trade fairs. According to a government decision of 1997 subsidies can be provided for the contracting of market research by exporters. Subsidies can also be provided for the organisation of educational activities such as seminars and conferences by exporters. In addition the government subsidises medium- and small-scale enterprises for their hiring of skilled personnel. The aim is to increase the productivity of the exporters concerned. Finally, Turkey subsidises activities related with the promotion of trademarks, opening of branch offices in foreign countries, patents and industrial designs. $^{7}$

\footnotetext{
${ }^{7}$ The export subsidies summarised above are consistent with WTO rules.
} 
TABLE 6

Cash Export Subsidies, 2004

\begin{tabular}{|c|c|c|c|c|c|}
\hline$H S$ & Commodity & $\begin{array}{l}\text { Cash } \\
\text { Subsidies }\end{array}$ & $\begin{array}{l}\text { Maximum } \\
\text { Subsidy Rate } \\
\text { (Per cent) }\end{array}$ & $\begin{array}{l}\text { Share of } \\
\text { Exported } \\
\text { Quantity } \\
\text { Eligible for } \\
\text { the Subsidy } \\
\text { (Per cent) }\end{array}$ & $\begin{array}{l}\text { Exports } \\
\text { in } 2003 \\
(U S \$ 1,000)\end{array}$ \\
\hline 0207 & $\begin{array}{l}\text { Meat and edible offal of poultry (excluding 02071391, 02071399, } \\
02071491,02072691,02072699,020734,02073591,02072791 \text {, } \\
02072799,02073599,02073681,02073685,02073689 \text { ) }\end{array}$ & $\$ 186 /$ tonne & 20 & 14 & 15,887 \\
\hline 040700 & Birds'eggs, in shell, fresh, preserved or cooked & $\$ 6 / 1,000$ units & 10 & 78 & 10,676 \\
\hline 040900 & Honey & $\$ 65 /$ tonne & 10 & 32 & 37,090 \\
\hline 060310 & Fresh cut flowers and flower buds of a kind suitable for bouquets & $\$ 205 /$ tonne & 20 & 37 & 14,816 \\
\hline 070190 & Potatoes & $\$ 20 /$ tonne & 15 & & 16,607 \\
\hline 070310190011 & Onions & $\$ 17 /$ tonne & 15 & & 15,050 \\
\hline 0710 & $\begin{array}{l}\text { Vegetables (uncooked or cooked by steaming or boiling in water) } \\
\text { (excluding 071010) }\end{array}$ & $\$ 79 /$ tonne & 20 & 27 & 39,188 \\
\hline 0712 & Dried vegetables, whole, cut, sliced, broken or in powder & $\$ 370 /$ tonne & 10 & 20 & 30,291 \\
\hline 0811 & Fruits and nuts, uncooked or cooked by steaming or boiling & $\$ 78 /$ tonne & 20 & 41 & 32,265 \\
\hline 1604 & Prepared or preserved fish & $\$ 200 /$ tonne & 15 & 100 & 10,520 \\
\hline 1806 & Chocolate and other food preparations containing cocoa & $\$ 119 /$ tonne & 10 & 48 & 129,795 \\
\hline 1902 & Pasta & $\$ 66 /$ tonne & 10 & 32 & 26,848 \\
\hline 190530 & Sweet biscuits; waffles (including 19059040, 19059045) & $\$ 119 /$ tonne & 10 & 18 & 66,648 \\
\hline $\begin{array}{l}2001,2002,2003, \\
\quad 2004,2005,2006, \\
2008\end{array}$ & $\begin{array}{l}\text { Vegetables, fruits, nuts and other edible parts of plants, tomatoes } \\
\text { prepared or preserved, mushrooms, truffles, other vegetables } \\
\text { prepared or preserved. Fruits, nuts, and other edible parts of plants } \\
\text { (excluding } 200811,20081911,20081913,200819190014 \text {, } \\
200819190039,200819190049,20081951,20081959,20081993 \text {, } \\
20081999,200819950014,200819950039,200819950049)\end{array}$ & $\$ 68 /$ tonne & 20 & 51 & 540,160 \\
\hline 2007 & $\begin{array}{l}\text { Jams, fruit jellies, marmalades, fruit or net purée } \\
\text { (excluding 20079920, 20079951, 200799980019) }\end{array}$ & $\$ 63 /$ tonne & 20 & 35 & 58,613 \\
\hline 2009 & Fruit juices (excluding 200990) & $\$ 134 /$ tonne & 20 & 17 & 72,584 \\
\hline
\end{tabular}

Source: www.igeme.gov.tr 
Export taxes apply at the rate of $\$ 0.04$ per $\mathrm{kg}$ on shelled hazelnuts and $\$ 0.08$ per kg on unshelled hazelnuts. Semi-processed leather is subject to an export tax at the rate of $\$ 0.5$ per $\mathrm{kg}$.

Since passage of the Turkish law on free zones in 1985, 20 zones have been established. The zones are open to a wide range of activity, including manufacturing, storage, packaging, trading, banking and insurance. Foreign products enter and leave the free zones without payment of any customs or duties. Income generated in the zones is exempt from corporate and individual income taxation and from the value-added tax, but firms are required to make social security contributions for their employees. Additionally, standardisation regulations in Turkey do not apply to the activities in the free zones, unless the products are imported into Turkey. In contrast to most other free zones, sales to the Turkish domestic market are allowed. Goods and revenues transported from the zones into Turkey are subject to all relevant import regulations. There are no restrictions on foreign firms' operations in the free zones. ${ }^{8}$

\section{LIBERALISATION OF SERVICES}

In 2003, the services contributed 63.6 per cent to GDP, and employed 47.9 per cent of the labour force. While exports of services amounted during 2003 to $\$ 19.0$ billion, imports of services amounted to $\$ 8.5$ billion. Among the services, tourism is a major net foreign exchange earner. The sector is dominated by several state-owned enterprises. Some of these companies still operate under monopoly, or hold exclusive rights in several branches of the sector.

Turkey has made, as emphasized above, extensive commitments under GATS. Its schedule covers 72 activities out of a total of 161 in nine sectors. Turkey maintains MFN exemptions under Article II of the GATS, reserving the right to offer more favourable treatment to some WTO members in some specific areas of business, communication, financial and transport services. It became a party to the Interim Agreement on Financial Services in 1995, the 1997 Information Technology Agreement, the 1997 Agreement on Telecommunications Services, and the 1997 Agreement on Financial Services.

Services are not covered by the customs union agreement between Turkey and the EU. As part of the pre-accession strategy for Turkey, negotiations have started between Turkey and the EU on liberalisation of services in line with the TurkeyEU Association Council Decision of 11 April, 2000. Since joining the EU will require Turkey to adopt and implement the whole body of EU legislation in all areas - the acquis communautaire - Turkey will have to liberalise further its

${ }^{8}$ Free zones are not consistent with the EU rules on state aid. Turkey during the pre-accession period has to make the necessary changes. 
services sectors, and with accession it will be part of the European single market for services. Recently, Turkey has been implementing autonomous reforms in the various sectors of the economy such as banking, telecommunications, natural gas and electricity. ${ }^{9}$

\section{SUSTAINABILITY OF CURRENT ACCOUNT}

Figure 1 shows developments in the current-account-to-GDP over the period 1975-2004. ${ }^{10}$ Turkey has faced currency crises in the late 1970s, 1994 and 2001. The figure indicates that the probability of a balance of payments crisis increases in Turkey as the current-account-deficit-to-GDP ratio increases above the critical level of 5 per cent. ${ }^{11}$ In 2004 the annual current account deficit amounted to $\$ 15.4$

FIGURE 1

Current-Account-to-GDP Ratio, 1975-2004

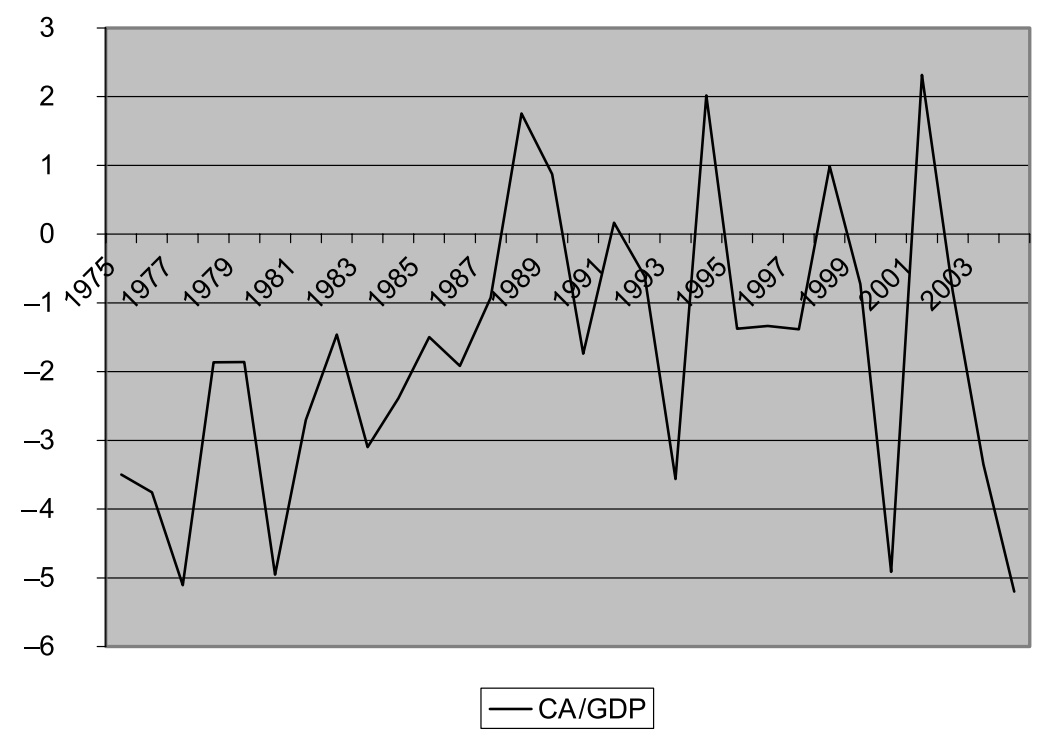

Source: Central Bank of Turkey.

${ }^{9}$ For consideration of reform efforts in the banking sector see Pazarbaşığlu (2005); for the telecommunications sector see Akdemir et al. (2005); for the natural gas sector see Mazanti and Biancardi (2005); for the electricity sector see Atiyas and Dutz (2005); and for the transport sector see Francois (2005).

10 This section draws heavily on Togan and Ersel (2005).

11 We do not state that large current account deficits are the only cause of the currency crises. During the periods prior to the crises current account deficits were financed mainly by short-term foreign borrowing. There were also other weaknesses in the Turkish economy. The 1994 and 2001 crises occurred when the country was facing large fiscal deficits, huge public debts, problems in the 
billion, and the current-account-deficit-to-GDP ratio has increased to 5.1 per cent. The deficit is funded mainly by short-term funds, and foreign direct investment inflows remain weak. Total foreign debt of Turkey in 2004 reached \$161.7 billion or 53.4 per cent of GDP, which reflects a significantly higher level of indebtedness than in other emerging countries.

Figure 2 shows the time path of the real exchange rate (RER) over the last two decades. ${ }^{12}$ The figure reveals four episodes of RER developments. After the foreign exchange crisis of the late 1970s, the government pursued a policy of RER depreciation. ${ }^{13}$ The policy continued until 1988. After 1988 the governing political party changed the policy of RER depreciation. RER started to appreciate. ${ }^{14}$ In

banking sector, and high inflation rates. Budget deficit measured by the public sector borrowing requirements-to-GNP ratio amounted to 10.9 per cent during 1991-93, and to 10.4 during 19942003. Inflation rate during 1990-2000 fluctuated between 54.9 and 106.3 per cent, and average inflation rate amounted to 75.2 per cent. There were distortions created by the state banks, which had a substantial share in the banking sectors' total assets. These banks faced unrecovered costs from duties carried out on behalf of the government, and they covered their financing needs from markets by borrowing at high interest rates and short maturities. Currency and maturity mismatches on the balance sheets of the banks had left the public authorities little leeway for using either interest-rate or exchange rate adjustments to restore balance without undermining the stability of the banking sector. In addition Turkey lacked in the banking sector competent supervisory authorities and a regulatory framework. Thus Turkey before the 2001 crisis had neither resolved its fiscal problems, nor attained price stability and a sound banking sector. There were also major problems with governance in general.

${ }_{12}$ When constructing real exchange rate indices one is faced with four decisions: choice of the price index, choice of the currency basket, choice of weights and choice of mathematical formula. In the formulation of the real exchange rate we use CPI as CPI data are available on a monthly basis for a large number of countries. Choice of currency basket is composed of countries which are major competitors of Turkey in world markets as well as major suppliers of imported commodities to Turkey. The countries considered consist of: in Western Europe: Belgium, France, Germany, Greece, Italy, Netherlands, Portugal, Spain, Switzerland and the UK; in America: Brazil, Canada, Mexico and the US; in the Central and Eastern European and Commonwealth of Independent States Countries: Czech Republic, Hungary, Poland, Russia; in Asia: China, Indonesia, Japan, Korea, Malaysia, Taiwan and Thailand; and in the Middle Eastern and North African countries: Egypt, Tunisia and Morocco. For weights assigned to different countries and formula used for estimation of RER we use the approach developed by Zanello and Desruelle (1997).

${ }^{13}$ Until the end of the 1970s, Turkey followed a fixed and multiple exchange rate policy while experiencing relatively high inflation rates. The policy led to a loss of competitiveness and eventually to the foreign exchange crisis of the late 1970s. The GNP shrank by 0.5 per cent in 1979 and by 2.8 per cent in 1980 . With the stabilisation measures of 1980 , Turkey devalued its lira by about 100 per cent and eliminated the multiple exchange rate system. After May 1981, the exchange rate was adjusted daily against major currencies to maintain the competitiveness of Turkish exports. Multiple currency practices were phased out during the first two years of the 1980 stabilisation programme, and the government pursued a policy of depreciating the RER - on average by about 6 per cent annually over the period $1980-88$.

${ }^{14}$ A drawback of the RER depreciation policy pursued during the 1980s was the decline in real wages, measured in terms of foreign currency. By the second half of the 1980s, popular support for the government had begun to fall off. In the local elections of March 1989, the governing political party suffered heavy losses. To increase political support, the government conceded substantial pay increases during collective bargaining in the public sector. Pressure then built up in the private sector to arrive at similarly high wage settlements, and real wages began to increase and the RER 
1989 foreign exchange operations and international capital movements were liberalised entirely. ${ }^{15}$ According to the government, the appreciation of the RER experienced after 1989 stemmed from market forces. During the 1990s, Turkey's public finances had deteriorated considerably. The large public sector deficits were financed by borrowing from the market at very high real interest rates. ${ }^{16}$ Significant capital flowed into the country because it was offering not only high real interest rates but also the prospect of steady real appreciation of the exchange rate. Thus the government's implicit commitment to the RER appreciation insured the private sector, domestic and foreign, against currency risk. It encouraged capital inflows from abroad and lending to the public sector, giving rise to the phenomenon of large, arbitrage-related, short-term capital inflows. The appreciation of the RER carried on under various coalition governments until 1994 when the country was faced with another currency crisis. The RER depreciated sharply in April 1994, but thereafter it started to appreciate again. The appreciation of the RER carried on until February 2001, when the country was

started to appreciate. To clarify the relation between RER and real wages let $p^{*} E / p$ be the RER where $p^{*}$ denotes the GDP deflator in the foreign country, $E$ the exchange rate measured as domestic currency units per unit of foreign currency and $p$ the GDP deflator in the home country, and $p y=w L+r K$ the nominal GDP where $y$ stands for real GDP, $w$ the nominal wage rate, $L$ total employment, $r$ the return on capital and $K$ the stock of capital. Expressing the capital income in the above equation as $r K=\lambda(w L)$, where $\lambda$ stands for the mark-up rate, the RER can be written as $\frac{E p^{*}}{p}=\frac{(y / L) E w^{*}\left(1+\lambda^{*}\right)}{\left(y^{*} / L^{*}\right)(1+\lambda) w}$, where $(y / L)$ denotes labour productivity in the home country, $\left(y^{*} / L^{*}\right)$ labour productivity in the foreign country, $\lambda *$ the mark-up rate in the foreign country and $w^{*}$ the wage rate in the foreign country. Thus, developments in the RER depend on developments in the productivity ratio $\frac{\rho}{\rho^{*}}$, relative wage ratio $\frac{w}{E w^{*}}$, and on the relative mark-up ratio $\frac{(1+\lambda)}{\left(1+\lambda^{*}\right)}$. Hence, for constant values of productivity ratio and relative mark-up ratio, an increase in the relative wage ratio $\frac{w}{E w^{*}}$ implies appreciation of the RER.

15 Turkey opened the capital account in 1989 before it had taken measures to upgrade banking and financial market supervision and regulation, adopt international auditing and accounting standards, strengthen corporate governance and shareholder rights, and modernise bankruptcy and insolvency procedures.

${ }^{16}$ Real interest rate is defined as $r_{t}=\left[\left\{\frac{1+\left(\frac{i_{t}}{100}\right)}{1+\left(\frac{\pi_{t}}{100}\right)}\right\}-1\right] * 100$, where $i_{t}$ denotes the annual rate of interest on government bonds and treasury bills, attained as the weighted average rate in auctions during the month $t$ weighted by total sales during the month, and $\pi_{t}$ denotes the expected annual rate of inflation at time $t$ over the period $t$ to $t+12$. In the calculations of the real interest rate, we set the expected annual rate of inflation at time $t$ over the period $t$ to $t+12$ equal to the actual annual rate of inflation over the period $t$ to $t+12$. The average level of real interest rates over the period January 1991 to March 1993 amounted to 9 per cent, and between February 1994 and October 2003 to 25.5 per cent. 
FIGURE 2

Real Exchange Rate, 1980-2004

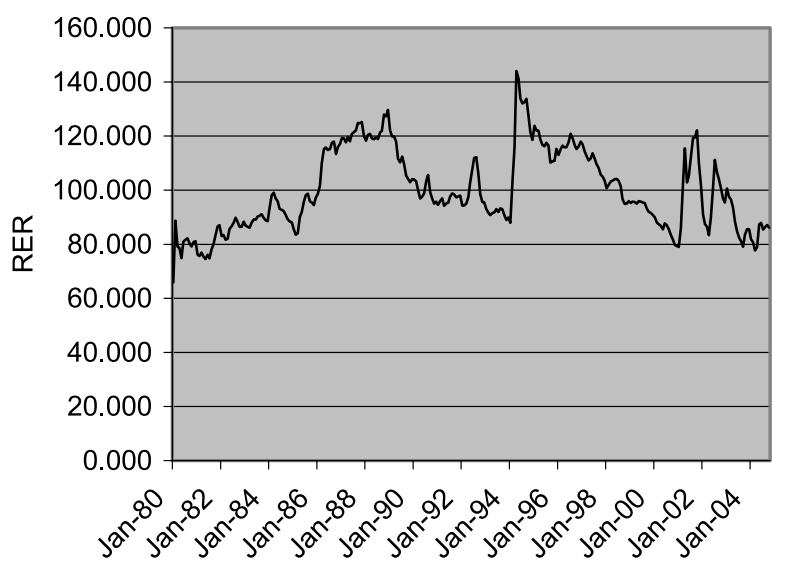

Source: The author.

faced with yet another currency crisis. After the sharp depreciation of the RER from February 2001 to April 2001, it began to appreciate, in particular after October 2001. It has appreciated during October 2001 and October 2004 by about 30 per cent. With the appreciation of the RER considerable economic recovery was observed in 2002 and thereafter.

The above considerations reveal how important current account sustainability is for a country like Turkey. ${ }^{17}$ Here our basic presumption is that if the current account is not sustainable, then the country is expected to face an exchange rate collapse or an external debt default. Starting from the notion that under current account sustainability the country must satisfy its lifetime budget constraint, we say that the current stance of policies are sustainable if the continuation of the current government policy stance and private sector behaviour into the future does not entail a drastic policy shift or lead to a currency or balance of payments crisis.

To clarify the concept of sustainability of the current account we make use of the balance of payments relation and show that current-debt-to-GDP ratio, $d_{t}$, equals the expected discounted present value of foreign debt outstanding in period $t+n$ relative to GDP, $\Gamma_{t} \delta_{t, n} d_{t+n}$, plus the sum of all discounted non-interest current account plus net FDI flows to GDP ratio between period $t$ and period $t+n, \Gamma_{t} \sum_{i=1}^{n} \delta_{t, i} A_{t+i}$, where $\delta_{t, k}$ denotes the ' $k$-periods ahead' discount factor used

17 The purpose of this section is to emphasise the relations between current account sustainability, real exchange rate, and domestic aggregate demand policies. Our purpose is not to discuss the factors leading to currency crises in general. These factors were mentioned briefly in footnote 11 above. 
to calculate the present value of assets and liabilities in period $t+k$ for period $t$, $\Gamma_{t} x_{t+k}$ the period $t$ expectation of the variable $x$ in period $t+k, A_{t}=t b_{t}+f d i_{t}-\Delta r_{t}$, $t b_{t}$ the non-interest-current-account-to-GDP ratio, $f d i_{t}$ the FDI-to-GDP ratio, and $\Delta r_{t}$ the change in reserves-to-GDP ratio. ${ }^{18}$ To translate the intertemporal budget constraint into a practically more relevant requirement we consider the budget constraint for a limited period of time $n^{*}$ and add the sustainability condition that the discounted debt/GDP ratio at the end of period $t+n^{*}$ should not exceed the debt/GDP ratio at time $t .^{19}$

But this sustainability condition, while useful, is not easy to assess in practice. Even under initial negative $A_{t}$ values over the next few years the current account can be said to be sustainable if during the latter periods large positive noninterest-current-account-to-GDP and FDI-to-GDP and thus $A_{t+i}$ values are assumed. Consider the year 2004. During that year we had the following values for the variables under consideration: $d_{2004}=53.45$ per cent, $t b_{2004}=-3.54$ per cent,

${ }^{18}$ Consider the balance of payments relation, which can be written as $T B_{t}^{\$}-i^{*} D_{t-1}+F D I_{t}+D_{t}-$ $D_{t-1}-\Delta R_{t}=0$ where $T B^{\$}$ denotes the non-interest current account, $i^{*}$ the foreign rate of interest, $D$ the stock of foreign debt, $F D I$ the net foreign direct investment, $R$ the foreign exchange reserves of the country, and $\Delta R_{t}$ the change in reserves. Also, $\left(T B_{t}^{\$}-i^{*} D_{t-1}\right)=$ Current Account $_{t}$ and $\left(F D I_{t}+D_{t}-\right.$

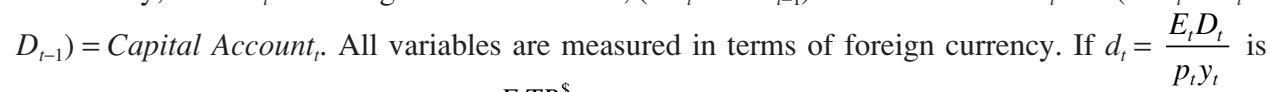
the foreign-debt-to-GDP ratio, $t b_{t}=\frac{E_{t} T B_{t}^{\$}}{p_{t} y_{t}}$ the non-interest-current-account-to-GDP ratio, $f d i_{t}=$ $\frac{F D I_{t} E_{t}}{p_{t} y_{t}}$ the FDI-to-GDP ratio, and $\Delta r_{t}=\frac{\left(\Delta R_{t}\right) E_{t}}{p_{t} y_{t}}$ the change-in-reserves-to-GDP ratio, the equation determining the time path of $d_{t}$ can be written as $d_{t}=-t b_{t}+\frac{\left(1+r^{*}\right)(1+\eta)}{(1+g)} d_{t-1}-f d i_{t}+\Delta r_{t}$ where $r^{*}$ denotes the foreign real rate of interest and $\eta$ the rate of depreciation of the RER. The equation reveals that the external-debt-to-GDP ratio decreases with increases in the non-interest-currentaccount-to-GDP ratio $t b$, the FDI-to-GDP ratio $f d i$, and the growth rate of GDP $g$. By contrast, the debt-to-GDP ratio increases with increases in the foreign real interest rate $r^{*}$, rate of depreciation of the RER $\eta$, and changes in the reserves-to-GDP ratio $\Delta r$.

Following the approach of von Hagen and Harden (1994), we solve this expression forward for $n$ periods and obtain $d_{t}=\Gamma_{t} \delta_{t, n} d_{t+n}+\Gamma_{t} \sum_{i=1}^{n} \delta_{t, i} A_{t+i}$ where $\delta_{t, k}=\prod_{i=1}^{k} \frac{1+g_{i}}{\left(1+r_{i}^{*}\right)\left(1+\eta_{i}\right)}$ and $A_{t}=t b_{t}+f d i_{t}-$ $\Delta r_{t}$. Here, $\delta_{t, k}$ can be interpreted as the ' $k$-periods ahead' discount factor used to calculate the present value of assets and liabilities in period $t+k$ for period $t . \Gamma_{t} x_{t+k}$ denotes the period $t$ expectation of the variable $x$ in period $t+k$. The equation shows that current-debt-to-GDP ratio equals the expected discounted present value of foreign debt outstanding in period $t+n$ relative to GDP, plus the sum of all discounted $A_{t}$ 's between period $t$ and period $t+n$. Theoretically, the intertemporal budget constraint requires that $\lim \Gamma_{t} \delta_{t, n} d_{t+n} \leq 0$ as $n$ becomes very large, so that foreign debt remains bounded relative to GDP. If the intertemporal budget constraint were violated, private investors would realise that the government's liabilities would eventually exceed its revenueraising capabilities. As a result, the price of the debt of the country would fall to zero, and the country would see itself barred from international capital markets.

${ }^{19}$ Symbolically, the current account is said to be not sustainable if $S\left(n^{*}\right)=d_{t}-\Gamma_{t} \delta_{t, n} d_{t+n}=$ $\Gamma_{t} \sum_{i=1}^{n} \delta_{t, i} A_{t+i}<0$. 
$f d i_{2004}=0.62$ per cent, $\Delta r_{2004}=1.44$ per cent, $A_{2004}=-4.35$ per cent, $g_{2004}=8.9$ per cent, $\eta_{2004}=-6.45$ per cent, and $r_{2004}^{*}=5.2$ per cent. If the value of $A_{2004+i}$ over the next few years, say three years, were to remain negative the present value $\Gamma_{t} \sum_{i=1}^{n} \delta_{t, i} A_{t+i}$ could turn out to be positive if one were to assume sufficiently large positive future non-interest-current-account-to-GDP and FDI-to-GDP values over the latter periods, namely from 2008 onwards. Current account will then turn out to be sustainable. The analysis thus depends on the assumptions one makes about the evolution of $A_{2004+i}$ over time.

In the following we assume the continuation of the present policies into the future. In particular we introduce the following assumptions. We assume that $n^{*}$ $=10$, and that the government, private sector and rest of the world will not change the policies they pursue in period 2004 over the time period 2005 and 2014. In addition, we assume that there will be no accumulation/decumulation of international reserves and that the country will neither depreciate nor appreciate the RER over the next ten years so that $\Delta r_{t+i}=0$ and $\eta_{t+i}=0$ for $i=1, \ldots, 10$. We suppose that the values of $t b_{t+i}$ and $f d i_{t+i}$ for $i=1, \ldots, 10$ will remain unchanged at their initial values of $t b_{2004}$ and $f d i_{2004}$. Furthermore, we assume that real GDP will grow at the average rate of 4.1 per cent annually and that foreign real interest rate equals 6.86 per cent over the next ten years. ${ }^{20}$ Finally, we assume that $\Delta r_{2004}$ $=0$ so that $A_{2004}=-2.92$ per cent rather than the actual value of $A_{2004}=-4.36$ per cent. We then calculate the value of debt-to-GDP ratio in 2014 using the difference equation (1) and then the value of the sustainability measure (3).

When over the next ten years $A_{2004+i}$ stays constant at -2.92 per cent, current account in 2004 turns out to be unsustainable in the sense that the actual debt-toGDP ratio in 2004 falls short of the expected discounted present value of foreign debt outstanding in period 2014 by 25.31 per cent. The sustainability of the current account requires that the value of the sustainability measure be increased so that it becomes positive. This goal can be achieved either through an increase in the non-interest-current account-to-GDP ratio $t b_{t}$ or through an increase in the FDI-to-GDP ratio $f d i_{t}$ during the period $2005-14$ or through a combination of

\footnotetext{
${ }^{20}$ A look at Turkey's annual GDP growth rate over the period 1980-2004 reveals that the average growth rate of GDP amounted to 4.1 per cent during 1980-89 and again 4.1 per cent during 19902004. Hence, for the growth rate of GDP over the time period 2004 to 2014 we take the figure of 4.1 per cent. On the other hand, we determine the foreign interest rate from eurobond issues of the Turkish Treasury. The average rate of return on Turkish US\$ eurobonds during the time of issue was 10.13 per cent in $1998,12.08$ per cent during $1999,11.61$ per cent in $2000,11.35$ per cent in 2001, 10.66 per cent in 2002, 10.08 per cent in 2003 and 8.06 per cent in 2004. By deflating the nominal return figures by US CPI inflation rates observed during the following period we obtain as the average figure for the time period 1998-2004 7.84 per cent, and for the time period 2002-04 6.86 per cent. In the calculations we set the value of foreign real interest rate as 6.86 per cent. We would like to thank Tekin Çotuk of the Undersecretariat of the Treasury for providing the data on Turkish eurobonds.
} 
increases in both the non-interest-current-account-to-GDP and FDI-to-GDP ratios. For Turkey to achieve the minimal condition for external sustainability, the value of $A_{t}$ during each time period of the interval 2005-14 would have to be 0 per cent. Thus Turkey has to increase the sum of its non-interest-current-account-to-GDP ratio and its FDI-to-GDP ratio during each period of the interval 2005-14 by at least 2.92 per cent.

Suppose first that $f d i_{t}$ during the time period 2005-14 remains constant at its 2004 level of 0.62 per cent. Economic theory tells us that non-interest-currentaccount-to-GDP ratio can be increased by decreasing aggregate demand for domestic goods and services and/or by depreciating the RER. Decreasing the aggregate demand for goods and services requires that the country uses contractionary policies. But, Turkey as of the beginning of 2005 is already in the midst of a determined campaign to turn around decades of weak performance due to pervasive structural rigidities and weak public finances. Aiming for more ambitious fiscal objective than the constant primary surplus of 6.5 per cent of GNP will be very painful after so many failed stabilisation attempts. The alternative is to depreciate the RER and keep the RER around its 'long-run equilibrium level' over time. To determine the extent of depreciation in the RER required for achieving current account sustainability we consider the elasticity of the ratio of non-interest-current-account-to-GDP with respect to the RER,

$$
\theta=\left(\frac{d N I C A / G D P}{d R E R} \frac{R E R}{N I C A / G D P}\right)
$$

Then starting from initial trade balance we derive that

$$
\theta=\left(\eta_{i m}+\eta_{\text {exp }}-1\right)
$$

where $\eta_{i m}$ and $\eta_{\text {exp }}$ denote the import and export elasticities with respect to the RER. Estimates based on estimated Turkish import and export equations range quite widely. Here we consider the estimates of Tansel and Togan (1987) who determine the export price elasticity as 0.933 and import price elasticity as 0.472 . Thus, $\theta=0.405$. Considering the ratio of exports-to-GDP of 19.6 per cent, the parameter values imply that a reduction of the ratio of non-interest-currentaccount-to-GDP of 1 per cent requires a depreciation of the RER by 12.6 per cent. Thus sustainability of the current account requires that the RER be depreciated by 36.8 per cent.

Note that the above results were derived under the condition that $A_{2004+i}=0$ for $i=1, \ldots, 10$. Solving the difference equation determining the time path of foreign-debt-to GDP ratio dt given in footnote 18 for the value of foreign debt-toGDP ratio in 2014 with the values of $t b_{2004+i}=-0.62$ per cent, $f d i_{2004+i}=0.62$ per cent, $\Delta r_{2004+i}=0$ per cent, $g_{2004+i}=4.1$ per cent, $r_{2004+i}^{*}=6.86$ per cent and $\eta_{2004+i}$ 
$=0$ per cent we note that the debt-to-GDP ratio increases from its value of 53.45 per cent in 2004 to 69.43 per cent in 2014. The increase in debt-to-GDP ratio is thus perfectly compatible with the sustainability condition specified above.

An alternative specification of the sustainability condition requires that the ratio of the stock of foreign liabilities to GDP stay constant over time at its initial value in time period 2004. In that case, the equation determining the time path of the debt-to-GDP ratio $d$ can be solved for the equilibrium value of the sum of $t b$ and $f d i$, under the assumption that $\Delta r=0$, as:

$$
(t b+f d i)=-\left[\frac{\left(g-r^{*}-\eta-r^{*} \eta\right)}{(1+g)}\right] d,
$$

where $\eta$ denotes the rate of depreciation of the RER, $g$ the growth rate of real GDP and $r^{*}$ the foreign real interest rate. Considering the same parameter values as before, the equilibrium value of $(t b+f d i)$ is determined to be 1.42 per cent. ${ }^{21}$ Because in 2004 the actual value of $\left(t b_{t}+f d i_{t}\right)$ equalled -2.92 per cent, Turkey needs to increase the sum of its non-interest-current-account-to-GDP and FDI-toGDP ratios over time by 4.34 per cent. Suppose again that $f d i_{t}$ over time stays constant at its 2004 level of 0.62 per cent. Then the increase in $t b_{t}$, and thus in $A_{t}$ over time, can be achieved by depreciating the RER by 54.7 per cent.

Finally, following the suggestion of Reinhart, Rogoff and Savastano (2003), we consider a case in which the country tries to decrease its ratio of stock of foreign liabilities to GDP from its initial value of 53.45 per cent to 40 per cent over a period of ten years. In that case, Turkey has to increase the sum of its non-interest-current-account-to-GDP ratio and its FDI-to-GDP ratio over time by 5.53 per cent. This change, under the assumption that $f d i_{t}$ over time stays constant at its 2004 level, requires that the RER be depreciated by 69.7 per cent.

Once Turkey is able to attract higher levels of FDI into the country, it does not need to depreciate its currency by as much as 36.8 or 69.7 per cent in order to attain sustainability in its current account. ${ }^{22}$ With increases in the FDI-to-GDP ratios, the depreciation rate of the RER required to attain sustainability in the current account decreases. When the FDI-to-GDP ratio increases to 3 per cent of

${ }^{21} \mathrm{We}$ assume as before that $\eta$ equals 0 and set the values of the parameters as $g=0.041, r^{*}=$ 0.0686 and $d_{2004}=0.5345$ for the year 2004 .

${ }^{22}$ The formulation of the sustainability problem through equation (1) assumes that FDI is a surer and safer form of external financing. Thus the analysis is the paper assumes that current account deficits financed mainly by FDI inflows does not lead to problems of sustainability of current account. But if FDI takes the form of purchases of stocks and if these shares can be liquidated easily in domestic markets, then it is possible to take the money out of the country as in other forms of investment. In those cases FDI makes no difference and there is no reason to separate FDI flows in equation (1). Under these conditions sustainability of the current account will require higher rates of depreciation of the RER than those obtained above. 
GDP, then the system becomes sustainable under the approach of von Hagen and Harden (1994) when the RER is depreciated by 6.7 per cent. On the other hand, when the ratio of the stock of foreign liabilities to GDP stay constant over time at its initial value in time period 2004, the system becomes sustainable when the RER is depreciated by 24.7 per cent. Finally, to reduce the debt-to-GDP ratio to 40 per cent over a period of ten years, the RER needs to be depreciated by 39.7 per cent.

Finally, in order to determine the robustness of the analysis we consider pessimistic and optimistic scenarios. Under the pessimistic scenario we assume that $g=$ 0.031 and $r^{*}=0.0786$ and under the optimistic scenario we have $g=0.051$ and $r^{*}=0.0586$. Under the pessimistic (optimistic) scenario when the FDI-to-GDP ratio stays constant at 0.62 per cent of GDP over the period 2005-14, the system becomes sustainable under the approach of von Hagen and Harden (1994) when the RER is depreciated as before by 36.8 per cent. On the other hand, when the ratio of the stock of foreign liabilities to GDP stay constant over time at its initial value in time period 2004, the system becomes sustainable when the RER is depreciated by 67.9 (41.6) per cent. Finally, to reduce the debt-to-GDP ratio to 40 per cent over a period of ten years, the RER needs to be depreciated by 81.6 (58.1) per cent. When the FDI-to-GDP ratio increases over time from its value of 0.62 per cent, the required rate of depreciation of the RER in order to attain sustainability in the current account decreases with increases in the FDI-to-GDP ratio.

The sustainability analysis reveals that the exchange rate as of the beginning of 2005 is overvalued. According to Eichengreen and Choudhry (2005) the standard advice in such a situation would be: (i) increasing exchange rate flexibility, (ii) maintaining capital account restriction, (iii) strengthening prudential supervision, (iv) sterilising inflows, (v) loosening monetary policy, (vi) tightening fiscal policy, and (vii) negotiating a programme with the IMF. Currently, the Turkish exchange rate regime is an independent float. The Central Bank of Turkey (CBT) intervenes in the foreign exchange market in a strictly limited fashion to prevent excessive volatility without targeting a certain trend level. Regarding the second point we note that Turkey is committed not to impose any restrictions to capital account transactions. Regarding the third point it should be stressed that the soundness of the banking system is considered by Turkey as an important element for attaining a sustainable regime for capital movements. The country has been trying to develop effective systems of supervision and the necessary administrative capacity to enforce the rules in particular since the 2001 financial crisis. It realises that both domestic and international banks operating in the country should be sound and stable institutions. ${ }^{23}$ Regarding the fourth point we note that

\footnotetext{
${ }^{23}$ However, the country still faces problems in the real sector. There is a need to strengthen corporate governance, and there is also a large informal sector in the economy, where accounting practices need to be improved.
} 
the CBT has purchased foreign exchange through market-friendly auctions: the mechanism through which the CBT purchased foreign exchange and how much it was going to purchase daily were set in advance and announced. Whenever the reverse dollarisation process and capital inflows stopped, the CBT also stopped opening purchase auctions. In other words, it has not been aggressive in reserve accumulation. Through foreign exchange purchase auctions, the CBT purchased (as mentioned by Özatay, 2005) US $\$ 0.8$ billion in 2002, $\$ 5.7$ billion in 2003, and $\$ 4.1$ billion in 2004. CBT did not open purchase auctions in nine months in 2002, six months in 2003, and seven months in 2004. During 2005 CBT intends to have daily auctions where it will buy foreign exchange between minimum and maximum amounts. These preannounced amounts have been set as $\$ 15$ million and $\$ 45$ million daily.

Regarding the fifth point it should be emphasised that Turkey is following an implicit inflation targeting policy, and will introduce inflation targeting explicitly in 2006. Monetary policy will be used for attaining the inflation target. Regarding the sixth point, we note that Turkey is following tight fiscal policy. It is committed to keep the primary surplus at 6.5 per cent of GDP over the next three years. Aiming for a more ambitious fiscal objective than the constant primary surplus of 6.5 per cent of GDP will be very painful. Finally, Turkey has negotiated recently another three-year stand-by arrangement with the IMF. Thus Turkey has been trying to follow the policies under (i), (iii), (vi), (vii) and also partially (iv).

If Turkey intends to reverse the appreciation of the RER and attain sustainability in the current account there seem to be, in principle, three feasible policy alternatives: (1) taking measures to increase FDI inflow into Turkey, (2) changing the exchange rate regime from independent float to crawling bands or managed float, and (3) imposing restrictions on capital account transactions. ${ }^{24}$

\section{CONCLUSION}

The Trade Policy Review: Turkey 2003 (TPR) is a valuable document, a compendium of information on various aspects of Turkey's economic policy and performance. The TPR praises Turkey for its trade policies pursued through a wide network of bilateral and regional trade agreements, with a view to bringing its trade regime into line with its customs union on industrial products with the EU. While commending Turkey for conforming to the commitments to the multilateral trading system, the report points out among others the following issues for improvement. With regard to macroeconomic policies, it highlighted the importance of attaining macroeconomic stability. It stressed the need to speed up

${ }^{24}$ See Togan and Ersel (2005) for a discussion of these points. 
privatisation. With regard to trade policies, the report states that only 46.3 per cent of tariff lines are bound. Turkey, by increasing the percentage of bound tariff lines and then decreasing the average level of bound tariff rates, will introduce more predictability to its trade regime. In addition, the report stresses that agriculture and services are highly protected in Turkey. According to TPR, Turkey will benefit from further liberalisation of agricultural and services sectors. Finally, Turkey needs to take measures to increase foreign direct investment flows. In addition to the points emphasised in the TPR, we believe that Turkey needs to pay attention to the issue of sustainability of the current account.

\section{REFERENCES}

Akdemir, E., E. Başçı and G. Locksley (2005), 'A Comparative Analysis of Turkish Telecommunications Sector', in B. Hoekman and S. Togan (eds.), Turkey: Economic Reform and Accession to the European Union (The World Bank, forthcoming).

Atiyas, I. and M. Dutz (2005), 'Competition and Regulatory Reform in the Turkish Electricity Industry', in B. Hoekman and S. Togan (eds.), Turkey: Economic Reform and Accession to the European Union (The World Bank, forthcoming).

Commission of the European Communities (2004), 'Regular Report on Turkey's Progress Towards Accession - 2004,' COM(2004) 656 final (Brussels).

Dutz, M., M. Us and K. Yilmaz (2005), 'Foreign Direct Investment Challenges: Competition, the Rule of Law, and EU Accession', in B. Hoekman and S. Togan (eds.), Turkey: Economic Reform and Accession to the European Union (The World Bank, forthcoming).

Eichengreen, B. and O. Choudhry (2005), 'Managing Capital Inflows: Eastern Europe in an Asian Mirror', paper presented at the Turkish Central Bank Conference on Macroeconomic Policies for EU Accession (Ankara, 6-7 May).

European Commission (2000), 'Guide to the Implementation of Directives based on the New Approach and the Global Approach', (Brussels).

Foreign Investment Advisory Service (2001a), 'Turkey: A Diagnostic Study of the Foreign Direct Investment Environment' (World Bank and the Treasury of Turkey, Ankara).

Foreign Investment Advisory Service (2001b), 'Turkey: Administrative Barriers to Investment' (World Bank and the Treasury of Turkey, Ankara).

Francois, J. (2005), 'Accession of Turkey to the EU: Implications for the Transportation Sector', in B. Hoekman and S. Togan (eds.), Turkey: Economic Reform and Accession to the European Union (The World Bank, forthcoming).

Mazzanti, M. R. and A. Biancardi (2005), 'Institutional Endowment and Regulatory Reform in Natural Gas', in B. Hoekman and S. Togan (eds.), Turkey: Economic Reform and Accession to the European Union (The World Bank, forthcoming).

Organisation for Economic Co-operation and Development (2004), OECD Economic Surveys: Turkey (Paris: OECD).

Özatay, F. (2005), 'Monetary Policy Challenges for Turkey in European Union Accession Process', paper presented at the Turkish Central Bank Conference on Macroeconomic Policies for EU Accession (Ankara, 6-7 May).

Pazarbaşıŏlu, C. (2005), 'Costs of European Union Accession: The Potential Impact on Turkish Banking Sector', in B. Hoekman and S. Togan (eds.), Turkey: Economic Reform and Accession to the European Union (The World Bank, forthcoming).

Reinhart, C., K. Rogoff and M. Savastano (2003), 'Debt Intolerance', Brookings Papers on Economic Activity, 1-74.

Tansel, A. and S. Togan (1987), 'Price and Income Effects in Turkish Foreign Trade', Weltwirtschaftliches Archiv, 123, 521-34. 
Togan, S. and H. Ersel (2005), 'Macroeconomic Policies for Turkey's Accession to the EU', in B. Hoekman and S. Togan (eds.), Turkey: Economic Reform and Accession to the European Union (The World Bank, forthcoming).

von Hagen, J. and I. J. Harden (1994), 'National Budget Process and Fiscal Performance', European Economy. Reports and Studies 3. Towards Greater Fiscal Discipline, 311-93.

Zanello, A. and D. Desruelle (1997), 'A Primer on the IMF's Information Notice System', IMF Working Paper WA/97/71 (Washington, DC: International Monetary Fund). 